\title{
Copper Induces Oxidative Stress and Apoptosis in the Mouse Liver
}

\author{
Huan Liu, ${ }^{1}$ Hongrui Guo, ${ }^{1,2}$ Zhijie Jian, ${ }^{1}$ Hengmin Cui $\mathbb{D}^{1,2,3}$ Jing Fang $\mathbb{D}^{1,2}$ Zhicai Zuo ${ }^{10},{ }^{1,2}$ \\ Junliang Deng $\mathbb{D},{ }^{1,2}$ Yinglun Li $\mathbb{D}^{1,2}$ Xun Wang $\mathbb{D}^{1,2}$ and Ling Zhao $\mathbb{D}{ }^{1,2}$ \\ ${ }^{1}$ College of Veterinary Medicine, Sichuan Agricultural University, Wenjiang, Chengdu 611130, China \\ ${ }^{2}$ Key Laboratory of Animal Diseases and Environmental Hazards of Sichuan Province, Sichuan Agriculture University, Wenjiang, \\ Chengdu 611130, China \\ ${ }^{3}$ Key Laboratory of Agricultural Information Engineering of Sichuan Province, Sichuan Agriculture University, Yaan, \\ Sichuan 625014, China
}

Correspondence should be addressed to Hengmin Cui; cui580420@sicau.edu.cn

Received 18 September 2019; Revised 24 November 2019; Accepted 13 December 2019; Published 11 January 2020

Academic Editor: Luciana Mosca

Copyright ( 2020 Huan Liu et al. This is an open access article distributed under the Creative Commons Attribution License, which permits unrestricted use, distribution, and reproduction in any medium, provided the original work is properly cited.

\begin{abstract}
Copper $(\mathrm{Cu})$ is an essential trace element involved in the normal physiological processes of animals. However, excessive exposure to $\mathrm{Cu}$ can produce numerous detrimental impacts. The aim of this study was to investigate the effects of $\mathrm{Cu}$ on oxidative stress and apoptosis as well as their relationship in the mouse liver. Four-week-old ICR mice $(n=240)$ were randomly assigned to different $\mathrm{Cu}(\mathrm{Cu} 2+-\mathrm{CuSO} 4)$ treatment groups $(0,4,8$, and $16 \mathrm{mg} / \mathrm{kg})$ for periods of 21 and 42 days. The high doses of Cu exposure could induce oxidative stress, by increasing the levels of reactive oxygen species (ROS) and protein carbonyls (PC) and decreasing the activities of antisuperoxide anion (ASA) and antihydroxyl radical (AHR) and content of glutathione (GSH), as well as activities and mRNA expression levels of superoxide dismutase (SOD), catalase (CAT), and glutathione peroxidase (GSH-Px). Moreover, high doses of $\mathrm{Cu}$ exposure induced hepatic apoptosis via the mitochondrial apoptotic pathway, as characterized by the depolarization of mitochondrial membrane potential (MMP); significantly increased mRNA and protein expression levels of cytosolic cytochrome (Cyt c), apoptosis-inducing factor (AIF), endonuclease G (Endo G), apoptosis protease-activating factor-1 (Apaf-1), cleaved caspase-9, cleaved caspase-3, cleaved PARP, Bcl-2 antagonist killer (Bak), Bcl-2-associated X protein (Bax), and Bcl-2-interacting mediator of cell death (Bim); and decreased mRNA and protein expression levels of B-cell lymphoma-2 $(\mathrm{Bcl}-2)$ and $\mathrm{Bcl}$-extra-large $(\mathrm{Bcl}-\mathrm{xL})$. Furthermore, the activation of the tumor necrosis factor receptor-1 (TNF-R1) signaling pathway was involved in $\mathrm{Cu}$-induced apoptosis, as characterized by the significantly increased mRNA and protein expression levels of TNF-R1, Fas-associated death domain (FADD), TNFR-associated death domain (TRADD), and cleaved caspase-8. These results indicated that exposure to excess $\mathrm{Cu}$ could cause oxidative stress triggered by ROS overproduction and diminished antioxidant function, which in turn promoted hepatic apoptosis via mitochondrial apoptosis and that the TNF-R1 signaling pathway was also involved in the $\mathrm{Cu}$-induced apoptosis.
\end{abstract}

\section{Introduction}

Copper $(\mathrm{Cu})$ is an essential trace element involved in the normal physiological processes of animals [1]. Despite its necessity for various metabolic processes and enzyme activities [2], chronic overexposure to $\mathrm{Cu}$ may produce some detrimental effects on our body. Generally, occupational exposure to $\mathrm{Cu}$ can result in $\mathrm{Cu}$ toxicity among industrial workers [3]. In animals, long-term intake of $\mathrm{Cu}$ compounds from different origins represents the most common form of $\mathrm{Cu}$ poisoning. The metabolism of $\mathrm{Cu}$ is mainly regulated by the liver, where it can be released into the circulatory system or excreted via the bile [1]. During chronic Cu toxicity, $\mathrm{Cu}$ is gradually accumulated in the liver without producing any obvious signs or symptoms. When the hepatic $\mathrm{Cu}$ storage capacity is exceeded, it may result in hepatocellular lesions, and consequently, the liberation of $\mathrm{Cu}$ from the liver into the blood stream triggers hemolysis, jaundice, and renal insufficiency [4].

Our previous studies have indicated that excessive $\mathrm{Cu}$ exposure can induce oxidative stress in the brain $[5,6]$ and spleen [7] in chicken, reduce the activities of copperzinc superoxide dismutase (CuZn-SOD) and glutathione 
peroxidase (GSH-Px), and increase the contents of malondialdehyde (MDA) and hydroxyl radical in the liver $[8,9]$ and kidney [10] of ducklings. Oxidative stress is considered to reflect an imbalance between the production of reactive oxygen species (ROS) and the ability of the body to detoxify this intermediate [11]. The overproduction of ROS affects mainly biomembranous unsaturated fatty acids and decreases membrane fluidity and disrupts membrane structure and function [12]. The findings from in vitro and in vivo studies have demonstrated that $\mathrm{Cu}$ possesses the capacity to initiate oxidative damage [13-17]. Ozcelik and coworkers [18] have also found that excess $\mathrm{Cu}$ exposure can induce oxidative stress and suppress the antioxidant defense system in the rat liver. However, much less is known about the exact mechanism of $\mathrm{Cu}$-induced oxidative stress in the liver.

It has been widely accepted that oxidative stress is an apoptotic inducer. Apoptosis, or programmed cell death, is a naturally occurring cell death process, which is responsible for the normal development and homeostasis in all multicellular organisms [19]. Cu-induced apoptosis has been reported in vivo [20]. As an intrinsic apoptosis pathway, the mitochondrial apoptosis pathway plays a key role in cell death. The key members in this pathway include B-cell lymphoma-2 (Bcl-2) family protein, mitochondrial proapoptosis proteins, and caspases. Several studies have demonstrated that $\mathrm{Cu}$ induces apoptosis in the liver via increasing the protein expression levels of caspase- 3 , caspase- 8 , caspase-9, and Bcl-2-associated X protein (Bax) [20, 21]. It has been found that overexposure to $\mathrm{Cu}$ can result in mitochondrial dysfunction and increase the protein expression levels of cytosolic cytochrome (Cyt c) in the chicken liver [22], mouse brain [23], and chicken testis [24]. Besides, the death receptor pathway is also one of the main apoptosis signaling pathways [25], which belongs to the extrinsic apoptosis pathway. At the cell surface level, some of the well-characterized death receptors include Fas receptor and tumor necrosis factor receptor-1 (TNF-R1) that can bind to tumor necrosis factor alpha (TNF- $\alpha$ ), a proinflammatory cytokine. Binding of TNF- $\alpha$ to TNF-R1 usually results in caspase activation and apoptosis [26]. At present, there are no reports about the relationship between $\mathrm{Cu}$-induced hepatic apoptosis and death receptor pathway. Also, the in vivo role of the mitochondrial apoptotic pathway in $\mathrm{Cu}$-induced hepatic apoptosis has not been reported thus far.

Based on the above findings, excess $\mathrm{Cu}$ intake can induce oxidative stress and apoptosis, but the underlying mechanisms remain unclear. There has been little systematic research focused on the relationship between oxidative stress and apoptosis in the mouse liver with excessive copper exposure. Hence, the present study was aimed at elucidating the possible molecular mechanism underlying $\mathrm{Cu}$-induced oxidative stress and apoptosis as well as their relationship in the mouse liver.

\section{Materials and Methods}

2.1. Chemicals. $\mathrm{Cu}$ sulfate was purchased from Chengdu Kelong Chemical Co., Ltd. (Chengdu, China). ROS Assay
Kit (88-5930-74) was obtained from Thermo Fisher, China. Reagent kits for the determination of biochemical parameters (protein carbonyls (PC), A087-2; MDA, A003-1; antihydroxyl radical (AHR), A018; antisuperoxide anion (ASA), A052; catalase (CAT), A007-1; glutathione reductase (GR), A062; glutathione (GSH), A006-2; GSH-Px, A005-a; glutathione-s-transferase (GST), A004; and superoxide dismutase (SOD), A001-1) were purchased from the Nanjing Jiancheng Bioengineering Institute of China (Nanjing, China). PrimeScript ${ }^{\mathrm{TM}}$ RT Reagent Kit (cat no. RR047A), SYBR ${ }^{\circledR}$ Premix Ex Taq ${ }^{\mathrm{TM}}$ II (cat no. RR820A), and RNAiso Plus (cat no. 9109) were supplied by Takara Biotechnology Co., Ltd. (Dalian, Liaoning, China). BD Pharmingen ${ }^{\mathrm{TM}} \mathrm{PE}$ Annexin V Apoptosis Detection Kit I (cat no. 559763) and Mitochondrial Membrane Potential Detection JC-1 Kit (cat no. 551302) were obtained from BD Bioscience (San Jose, CA, USA). Radioimmunoprecipitation assay (RIPA) lysis buffer (cat no. P0013C), phenylmethylsulfonyl fluoride (PMSF; cat no. ST506), tissue mitochondria isolation kit (cat no. C3606), and bicinchoninic acid (BCA) protein assay kit (cat no. P0012) were obtained from Beyotime Biotechnology (Nanjing, China). Mouse Cyt c (cat no. ab133504), endonuclease G (Endo G; cat no. ab76122), apoptosis-inducing factor (AIF; cat no. ab32516), Fas-associated death domain (FADD; cat no. ab124812), and TNFR-associated death domain (TRADD; cat no. ab110644) were purchased from Abcam (Cambridge, UK). Apoptosis protease-activating factor-1 (Apaf-1; cat no. 8723T), Bax (cat no. 2772), Bcl-2 antagonist killer (Bak; cat no. 12105), Bcl-2-interacting mediator of cell death (Bim; cat no. 2933), Bcl-2 (cat no. 2870), Bcl-extra-large (Bcl-xL; cat no. 2764), cleaved caspase-3 (cat no. 9664), cleaved caspase-9 (cat no. 9509), cleaved PARP (cat no. 5625), TNF-R1 (cat no. 13377S), cleaved caspase-8 (cat no. $8592 \mathrm{~T}$ ), anti-rabbit IgG (cat no. 7074), $\beta$-actin (cat no. 4970), and SDHA (cat no. 5839S) were obtained from Cell Signaling Technology (Danvers, MA, USA).

2.2. Animals and Treatments. Four-week-old healthy ICR mice ( $n=240$, half male and female) were purchased from the Experimental Animal Corporation of Dossy in Chengdu, China. Food and water were provided ad libitum. After 1 week of acclimatization, the mice were randomly divided into four different groups $(n=60)$. The control group received intragastric doses of distilled water, while the experimental groups received intragastric doses of 4,8 , or $16 \mathrm{mg} / \mathrm{kg}$ $\mathrm{Cu}\left(\mathrm{Cu}^{2+}\right.$-CuSO4; Chengdu Kelong Chemical Co., Ltd., Chengdu, China). Prior to the experiments, $\mathrm{Cu}$ sulfate was diluted with distilled water. The gavage doses for all the four groups were $1 \mathrm{~mL}$ per $100 \mathrm{~g}$ body weight once daily for 42 days. After 21 and 42 days of treatment, all mice were humanely killed and liver samples were collected from sacrificed mice for subsequent analyses.

The use of mice and all experimental procedures were approved by the Animal Care and Use Committee of Sichuan Agricultural University (Chengdu, China).

2.3. Detection of the Hepatic Growth Index. After body weights were recorded, eight mice per group were humanely killed on days 21 and 42 of the experiment. Weights were 
recorded for each liver. The liver growth index (GI) was calculated according to the following formula:

$$
\mathrm{GI}=\frac{\operatorname{organ} \text { weight }(\mathrm{mg})}{\text { body weight }(\mathrm{g})} \text {. }
$$

2.4. Detection of Hepatic Cu Concentration. $0.5 \mathrm{~g}$ portion of the liver samples ( $n=8$ per group, half male and female) was wet-digested with $9 \mathrm{~mL} \mathrm{HNO}_{3}$ and $1 \mathrm{~mL} \mathrm{HClO}_{4}$ (Chengdu Kelong Chemical Co., Ltd., China) for $24 \mathrm{~h}$ in the tube that can withstand high temperature. These tubes were then placed on a hot plate until the liquid was evaporated and the residue was suspended with $10 \mathrm{~mL} 0.1 \mathrm{M} / \mathrm{L}$ $\mathrm{HNO}_{3}$. Samples were then analyzed for $\mathrm{Cu}$ with a flame atomic absorption spectrophotometer (AAS700, PerkinElmer, USA).

2.5. Pathological Assessment. The liver samples $(n=8$ per group, half male and female) were fixed in $4 \%$ paraformaldehyde solution, dehydrated in ethanol, and embedded in paraffin. Then, serial slices at $4 \mu \mathrm{m}$ thickness were prepared and stained with hematoxylin and eosin (HE). Finally, the stained slices were subjected to histopathological examination using a light microscope.

2.6. Detection of Hepatocellular ROS Production by Flow Cytometry. The liver samples $(n=8$ per group, half male and female) were prepared immediately for the measurement of ROS levels by flow cytometry. Briefly, the liver samples were crushed, filtered through a 350-mesh nylon membrane, centrifuged at $600 \times g$ for $5 \mathrm{~min}$, and adjusted to a cell density of $1.0 \times 10^{6}$ cells $/ \mathrm{mL}$ with phosphate-buffered saline (PBS). Approximately $300 \mu \mathrm{L}$ of cell suspension was collected, transferred into a new centrifuge tube, and stained with $2^{\prime}-7^{\prime}$ dichlorofluorescin diacetate (DCFH-DA; $10 \mu \mathrm{M}$ ) for $20 \mathrm{~min}$ at $37^{\circ} \mathrm{C}$. Subsequently, the cells were washed with PBS and centrifuged again at $600 \times g$ for $5 \mathrm{~min}$. After discarding the supernatant, the cells were resuspended in $0.5 \mathrm{~mL}$ PBS and counted with a BD FACSCalibur flow cytometer.

2.7. Measurement of Oxidative and Antioxidant Parameters in the Liver. The liver samples ( $n=8$ per group, half male and female) were rinsed in chilled saline solution, weighed and homogenized in nine volumes of ice-cold $0.9 \% \mathrm{NaCl}$ solution, and centrifuged at $3500 \mathrm{rpm}$ for $10 \mathrm{~min}$ at $4^{\circ} \mathrm{C}$. The supernatants were collected for detecting the activities of CAT, GR, SOD, GST, GSH-Px, ASA, and AHR, as well as contents of GSH, MDA, and PC in the liver by biochemical methods according to the instructions of the reagent kits [27].

2.8. Detection of mRNA Expression Levels by $q R T-P C R$. The liver samples ( $n=8$ per group, half male and female) were stored in liquid nitrogen and homogenized for RNA extraction. The method of RNA extraction was the same as that described by $\mathrm{Lu}$ and coworkers [25]. The total RNA of the liver samples was extracted using RNAiso Plus (9109; Takara, China). The cDNA was synthesized using PrimeScript ${ }^{\mathrm{TM}} \mathrm{RT}$ Reagent Kit (RR047A; Takara, China) according to the man- ufacturer's instructions. The cDNA sequences of CAT, GR, GSH-Px, GST, CuZn-SOD, manganese superoxide dismutase (MnSOD), Cyt c, Endo G, AIF, Apaf-1, caspase-3, caspase-8, caspase-9, PARP, Bcl-2, Bax, Bak, Bim, Bcl-xL, TNF-R1, FADD, and TRADD were obtained from the NCBI database. $\beta$-Actin was used as a reference gene. The primers (see Table 1) were designed and synthesized by Sangon Biotech (Shanghai, China).

qRT-PCR amplification was performed on a Model C1000 Thermal Cycler (Bio-Rad, USA) using the SYBR ${ }^{\circledR}$ Premix Ex Taq ${ }^{\mathrm{TM}}$ II system (RR820A; Takara, China) according to the standard protocols. The relative expression level of each target gene was analyzed by the $2^{-\Delta \Delta \mathrm{CT}}$ method.

2.9. Evaluation of Hepatocyte Apoptosis by Flow Cytometry. The liver samples ( $n=8$ per group, half male and female) were ground to form a cell suspension that was filtered through a 350-mesh nylon screen. The cells were washed twice with cold PBS (phosphate buffer solution; $\mathrm{pH}$ 7.2-7.4) and then suspended in PBS to a final concentration of $1 \times$ $10^{6}$ cells $/ \mathrm{mL}$. Approximately $100 \mu \mathrm{L}$ of the cell suspension was transferred into a $5 \mathrm{~mL}$ culture tube and stained with $\mathrm{PE}$ Annexin $\mathrm{V}$ and 7-aminoactinomycin (7-AAD). The mixture was gently vibrated and incubated for $15 \mathrm{~min}$ in the dark. Then, $400 \mu \mathrm{L}$ of $1 \times$ binding buffer was added into each tube. Finally, the rates of hepatic apoptosis were analyzed by the BD FACSCalibur flow cytometer.

2.10. Analysis of Mitochondrial Membrane Potential (MMP) in Hepatocytes by Flow Cytometry. The liver samples $(n=8$ per group, half male and female) were ground to form a cell suspension and then filtered through a 350-mesh nylon screen. The cells were washed twice with ice-cold PBS ( $\mathrm{pH}$ 7.2-7.4) and suspended in PBS to a final concentration of 1 $\times 10^{6}$ cells $/ \mathrm{mL}$. Approximately $100 \mu \mathrm{L}$ of cell suspension was transferred into a $5 \mathrm{~mL}$ tube and then incubated with JC-1 $\left(5,5^{\prime}, 6,6^{\prime}\right.$-tetra-chloro-1,1 $1^{\prime}, 3,3^{\prime}$-tetraethylbenzimidazolyl-carbocyanineiodide) working solution for $15 \mathrm{~min}$ at $37^{\circ} \mathrm{C}$ in a $5 \% \mathrm{CO}_{2}$ incubator. The staining solution was removed, and the cells were washed twice with JC-1 staining buffer. Finally, MMP $(\Delta \Psi \mathrm{m})$ was measured by the BD FACSCalibur flow cytometer within $30 \mathrm{~min}$.

2.11. Detection of Protein Expression Levels by Western Blotting. Mitochondrial cytosolic protein was extracted according to the specification of a tissue mitochondria isolation kit. Total protein was extracted with the RIPA lysis buffer, and its concentrations were quantitated by a BCA protein assay kit. Protein samples were separated by $10 \%$ $15 \%$ sodium dodecyl sulfate-polyacrylamide gel electrophoresis (SDS-PAGE) and transferred onto nitrocellulose filter membranes. The membranes were then blocked with $5 \%$ fat-free milk for $1 \mathrm{~h}$, followed by overnight incubation with primary antibodies at $4^{\circ} \mathrm{C}$. The primary antibodies were Cyt c, AIF, Endo G, Apaf-1, cleaved caspase-3, cleaved caspase9, cleaved caspase-8, cleaved PARP, Bax, Bak, Bim, Bcl-2, Bcl-xl, TNF-R1, FADD, and TRADD. After washing with PBST (PBS-Tween), the membranes were incubated with biotin-conjugated secondary antibodies for $1 \mathrm{~h}$ and then 
TABLe 1: Primer sequences of genes selected for analysis by qRT-PCR.

\begin{tabular}{|c|c|c|c|c|c|}
\hline Target gene & Accession number & Primer & Primer sequence $\left(5^{\prime}-3^{\prime}\right)$ & Product size & $\operatorname{Tm}\left({ }^{\circ} \mathrm{C}\right)$ \\
\hline CAT & NM-009804 & Forward & CCTATTGCCGTTCGATTCTC & $119 \mathrm{bp}$ & 58.8 \\
\hline \multirow{3}{*}{ GR } & \multirow{3}{*}{ NM_010344 } & Reverse & CCCACAAGATCCCAGTTACC & \multirow{3}{*}{$121 \mathrm{bp}$} & \multirow{3}{*}{60.9} \\
\hline & & Forward & AAGCGCTTCTCACCCCAGTT & & \\
\hline & & Reverse & GGGTGGCTGAAGACCACAGTA & & \\
\hline GSH-Px & NM_008160 & Forward & TACACCGAGATGAACGATCTG & $102 \mathrm{bp}$ & 56.9 \\
\hline \multirow{3}{*}{ GST } & \multirow{3}{*}{ NM_019946 } & Reverse & ATTCTTGCCATTCTCCTGGT & \multirow{3}{*}{$121 \mathrm{bp}$} & \multirow{3}{*}{57.2} \\
\hline & & Forward & GGGATTGGCTGTGATGAGAT & & \\
\hline & & Reverse & AGGTAGGATGAATGGCAACTG & & \\
\hline CuZn-SOD & NM_011434 & Forward & GGGTTCCACGTCCATCAGTA & $113 \mathrm{bp}$ & 61 \\
\hline \multirow{3}{*}{ MnSOD } & \multirow{3}{*}{ NM_013671 } & Reverse & CAGGTCTCCAACATGCCTCT & \multirow{3}{*}{$113 \mathrm{bp}$} & \multirow{3}{*}{61} \\
\hline & & Forward & AACTCAGGTCGCTCTTCAGC & & \\
\hline & & Reverse & CTCCAGCAACTCTCCTTTGG & & \\
\hline Cyt c & NM_025567 & Forward & GGCTCСТСССАТСТАCACAG & $117 \mathrm{bp}$ & 56.4 \\
\hline \multirow{3}{*}{ Endo G } & \multirow{3}{*}{ NM_007931 } & Reverse & TCATGCTCTGGTTCTGATGC & \multirow{3}{*}{$119 \mathrm{bp}$} & \multirow{3}{*}{56.2} \\
\hline & & Forward & TCGAGCTACGTTCCTACGTG & & \\
\hline & & Reverse & ATTGGGCACGAAGAGCAATC & & \\
\hline AIF & NM_012019 & Forward & GATCAGGGCACCAAGTCACG & $146 \mathrm{bp}$ & 58.4 \\
\hline \multirow{3}{*}{ Apaf-1 } & \multirow{3}{*}{ NM_009684 } & Reverse & GAGGTCGCATGTATGGCAGT & \multirow{3}{*}{$120 \mathrm{bp}$} & \multirow{3}{*}{56.6} \\
\hline & & Forward & GCAAGGACACAGATGGTGGA & & \\
\hline & & Reverse & TCTGCTGAATCGCATGAACC & & \\
\hline Bax & NM_007527 & Forward & ATGCGTCCACCAAGAAGC & $163 \mathrm{bp}$ & 59.8 \\
\hline \multirow{3}{*}{ Bak } & \multirow{3}{*}{ NM_007523 } & Reverse & CAGTTGAAGTTGCCATCAGC & \multirow{3}{*}{$175 \mathrm{bp}$} & \multirow{3}{*}{57.7} \\
\hline & & Forward & CGCTACGACACAGAGTTCCA & & \\
\hline & & Reverse & CACGCTGGTAGACGTACAGG & & \\
\hline Bim & NM_207680 & Forward & CCTTCTGATGTAAGTTCTGAGTGTG & $113 \mathrm{bp}$ & 57.6 \\
\hline \multirow{3}{*}{$\mathrm{Bcl}-2$} & & Reverse & CCTTGCGGTTCTGTCTGTAG & & \\
\hline & NM_009741 & Forward & AGCCTGAGAGCAACCCAAT & $159 \mathrm{bp}$ & 58.7 \\
\hline & & Reverse & AGCGACGAGAGAAGTCATCC & & \\
\hline Bcl-xl & NM_009743 & Forward & TGTGGATCTCTACGGGAACA & $117 \mathrm{bp}$ & 56.4 \\
\hline & & Reverse & AAGAGTGAGCCCAGCAGAAC & & \\
\hline TNF-R1 & NM_011609 & Forward & AATGCAGACCTTGCGATTCT & $114 \mathrm{bp}$ & 57.8 \\
\hline & & Reverse & CATCTCCAGCCTCTCGATCT & & \\
\hline FADD & NM_010175 & Forward & CGTGAGAAACGAAAGCTGG & $142 \mathrm{bp}$ & 58.7 \\
\hline & & Reverse & CTGCAGTAGATCGTGTCGGC & & \\
\hline TRADD & NM_1033161 & Forward & TGGCTGACTGATGAAGAGCG & $112 \mathrm{bp}$ & 59.2 \\
\hline & & Reverse & CACACGTCAGTTTGCAGAGC & & \\
\hline Caspase-3 & NM_009810 & Forward & ACATGGGAGCAAGTCAGTGG & $149 \mathrm{bp}$ & 58.3 \\
\hline & & Reverse & CGTCCACATCCGTACCAGAG & & \\
\hline Caspase- 9 & NM_015733 & Forward & GAGGTGAAGAACGACCTGAC & $103 \mathrm{bp}$ & 58.8 \\
\hline & & Reverse & AGAGGATGACCACCACAAAG & & \\
\hline Caspase- 8 & NM_009812 & Forward & GCTGCCCTCAAGTTCCTGT & $118 \mathrm{bp}$ & 60.9 \\
\hline
\end{tabular}


TABLe 1: Continued.

\begin{tabular}{|c|c|c|c|c|c|}
\hline Target gene & Accession number & Primer & Primer sequence $\left(5^{\prime}-3^{\prime}\right)$ & Product size & $\operatorname{Tm}\left({ }^{\circ} \mathrm{C}\right)$ \\
\hline \multirow{3}{*}{ PARP } & \multirow{3}{*}{ NM_007415 } & Reverse & GATTGCCTTCСТCСАACATC & \multirow{3}{*}{$108 \mathrm{bp}$} & \multirow{3}{*}{57.8} \\
\hline & & Forward & СТСТССАATCGCTТСТАСАС & & \\
\hline & & Reverse & GTTGTCTAGCATCTCCACCT & & \\
\hline \multirow[t]{2}{*}{$\beta$-Actin } & \multirow[t]{2}{*}{ NM_007393 } & Forward & GCTGTGCTATGTTGCTCTAG & \multirow[t]{2}{*}{$117 \mathrm{bp}$} & \multirow[t]{2}{*}{60.9} \\
\hline & & Reverse & CGCTCGTTGCCAATAGTG & & \\
\hline
\end{tabular}

washed again with PBST. Finally, the protein blots were visualized by ECL $^{\mathrm{TM}}$ (Bio-Rad, Hercules, CA, USA) and X-ray film. The data of protein expression were analyzed using ImageJ2x software.

2.12. Statistical Analysis. To analyze the data, one-way analysis of variance (ANOVA) was carried out by using SPSS software version 18.0. All results were expressed as mean \pm standard deviation. $p<0.05$ was referred to as significant, and $p<0.01$ was considered highly significant.

\section{Results}

3.1. Changes of Body Weight, Hepatic Cu Concentration, and Hepatic Growth Index. $\mathrm{Cu}$, as an important trace element, is helpful for animal growth in an appropriate level. However, excessive intake of $\mathrm{Cu}$ may produce some detrimental effects on bodies. As shown in Figure 1(a), the mice in the 4, 8, and $16 \mathrm{mg} / \mathrm{kg} \mathrm{Cu}$ treatment groups grew much slower than those in the control group.

The levels of $\mathrm{Cu}$ accumulation in the liver were assessed at 42 days of the experiment. The result showed that $\mathrm{Cu}$ concentration in the liver was significantly higher $(p<0.01)$ in the $16 \mathrm{mg} / \mathrm{kg} \mathrm{Cu}$ treatment group than in the control group at day 42 of the experiment (Figure 1(b)).

Hepatic development is evaluated based on the hepatic growth index (GI) values. GI values were decreased $(p<0.05$ ) in the $16 \mathrm{mg} / \mathrm{kg} \mathrm{Cu}$ treatment group at day 42 of the experiment when compared to the control group (Figure 1(d)).

3.2. Histopathological Lesions in the Liver. As shown in Figure 2, the number of hepatic cells with granular and vacuolar degeneration was increased by $\mathrm{Cu}$ exposure in a doseand time-dependent manner. Tiny particles as well as small vacuoles could be found in the cytoplasm of these degenerated hepatocytes. Karyorrhexis, karyolysis, and hypochromatosis were observed in the necrotic hepatocytes, especially in the 8 and $16 \mathrm{mg} / \mathrm{kg} \mathrm{Cu}$ treatment groups. However, the above lesions were not observed in the control group.

3.3. Oxidative Stress Levels in the Liver. As shown in Figures 3(a) and 3(b), the levels of ROS production were increased $(p<0.05$ or $<0.01)$ in the 8 and $16 \mathrm{mg} / \mathrm{kg} \mathrm{Cu}$ treatment groups at days 21 and 42 and in the $4 \mathrm{mg} / \mathrm{kg} \mathrm{Cu}$ treatment group at day 42 when compared to the control group.

In addition, the contents of PC were increased $(p<0.05$ or $<0.01)$ in the three $\mathrm{Cu}$ treatment groups at days 21 and 42 (Figure 3(c)). However, MDA contents did not differ among all the four groups (Figure 3(c)). Besides, the abilities of ASA and AHR were decreased $(p<0.05$ or $<0.01)$ in the 8 and $16 \mathrm{mg} / \mathrm{kg} \mathrm{Cu}$ treatment groups at days 21 and 42 and in the $4 \mathrm{mg} / \mathrm{kg} \mathrm{Cu}$ treatment group at day 42 as compared to the control group.

3.4. Antioxidant Enzyme Activities and GSH Contents in the Liver. The activities of CAT were significantly decreased $(p<0.01)$ in the $16 \mathrm{mg} / \mathrm{kg} \mathrm{Cu}$ treatment group at days 21 and 42 as well as in the 4 and $8 \mathrm{mg} / \mathrm{kg} \mathrm{Cu}$ treatment groups at day 42 when compared to the control group (Figure 4(a)). Besides, the activities of GSH-Px were markedly lower $(p<0.01)$ in the 8 and $16 \mathrm{mg} / \mathrm{kg} \mathrm{Cu}$ treatment groups than in the control group at days 21 and 42. Similarly, the activities of SOD were significantly decreased $(p<0.01)$ in the 8 and $16 \mathrm{mg} / \mathrm{kg} \mathrm{Cu}$ treatment groups at days 21 and 42 as well as in the $4 \mathrm{mg} / \mathrm{kg} \mathrm{Cu}$ treatment group at day 42 . Likewise, the contents of GSH were decreased $(p<0.01)$ in the three $\mathrm{Cu}$ treatment groups at day 42 when compared with the control group. However, the activities of GR and GST were not significantly changed between the four groups. All results can be found in Figure 4(a).

3.5. The mRNA Expression Levels of Antioxidant Enzymes in the Liver. The melting curves of CAT, GR, GSH-Px, GST, CuZn-SOD, and MnSOD are presented in Figure 4(b), and there was only one peak for each PCR product. Compared with the control group, the mRNA expression levels of CAT were significantly lower $(p<0.01)$ in the $16 \mathrm{mg} / \mathrm{kg}$ $\mathrm{Cu}$ treatment group at days 21 and 42 as well as in the 4 and $8 \mathrm{mg} / \mathrm{kg} \mathrm{Cu}$ treatment groups at day 42 (Figure $4(\mathrm{c})$ )) The mRNA expression levels of GSH-Px were markedly decreased $(p<0.01)$ in the $16 \mathrm{mg} / \mathrm{kg} \mathrm{Cu}$ treatment group at days 21 and 42 as well as in the $8 \mathrm{mg} / \mathrm{kg} \mathrm{Cu}$ treatment group at day 21. The mRNA expression levels of GR, GST, CuZn-SOD, and MnSOD were reduced $(p<0.05$ or $<0.01$ ) in the 8 and $16 \mathrm{mg} / \mathrm{kg} \mathrm{Cu}$ treatment groups at days 21 and 42 as well as in the $4 \mathrm{mg} / \mathrm{kg} \mathrm{Cu}$ treatment group at day 42. On the contrary, the mRNA expression levels of these genes in the $4 \mathrm{mg} / \mathrm{kg} \mathrm{Cu}$ treatment group at day 21 were higher $(p<0.05$ or $<0.01)$ than those in the control group (Figure $4(\mathrm{c})$ ).

3.6. Apoptotic Rates and Depolarization of Mitochondrial Membrane Potential (MMP) in the Liver. The percentages of hepatic apoptosis were significantly higher $(p<0.01)$ in the 8 and $16 \mathrm{mg} / \mathrm{kg} \mathrm{Cu}$ treatment groups at days 21 and 42 as well as in the $4 \mathrm{mg} / \mathrm{kg} \mathrm{Cu}$ treatment group at day 42 than in the control group (Figures 5(a) and 5(c)). 


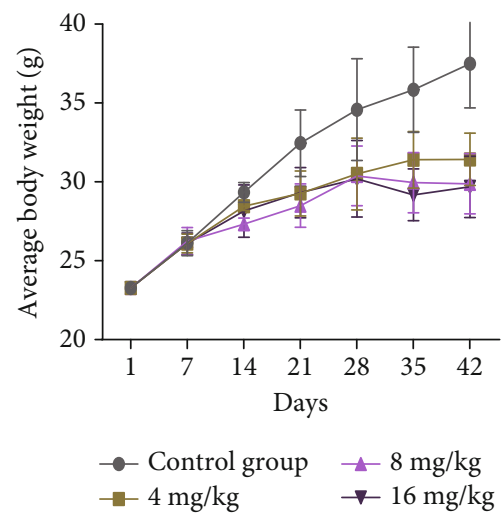

(a)

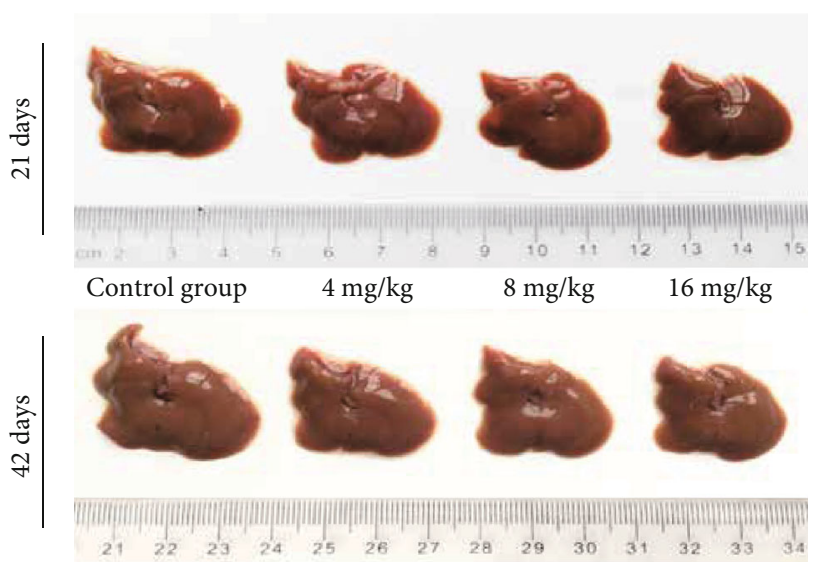

(c)

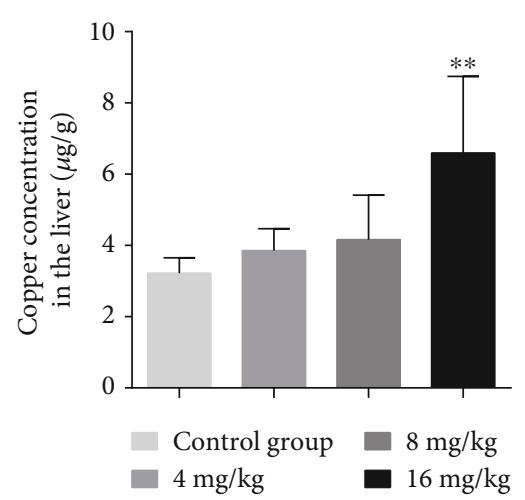

(b)

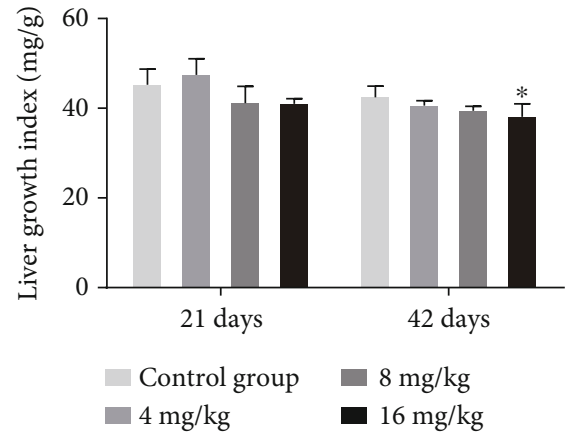

(d)

Figure 1

As shown in Figures 5(b) and 5(d), the proportions of hepatocytes depolarized with MMP collapse were significantly increased $(p<0.05$ or $<0.01)$ in the three $\mathrm{Cu}$ treatment groups at days 21 and 42 when compared to the control group.

\subsection{Changes in the Protein and $m R N A$ Expression Levels of} Mitochondrial Apoptosis-Related Parameters in the Liver. As presented in Figures 6(a) and 6(b), the protein levels of AIF, Endo G, and Apaf- 1 in the three $\mathrm{Cu}$ treatment groups at days 21 and 42 were significantly higher $(p<0.05$ or $<0.01)$ than those in the control group. The protein levels of cytosolic Cyt $c$ were increased $(p<0.05$ or $<0.01)$ in the 4 and $16 \mathrm{mg} / \mathrm{kg} \mathrm{Cu}$ treatment groups at days 21 and 42 as well as in the $8 \mathrm{mg} / \mathrm{kg} \mathrm{Cu}$ treatment group at day 42 when compared to the control group. Consistent with these protein expression data, the mRNA expression levels of AIF, Endo G, Apaf-1, and Cyt $c$ were upregulated $(p<0.05$ or $<0.01)$ in the three $\mathrm{Cu}$ treatment groups at days 21 and 42 when compared to the control group (Figures 6(c) and 6(d)).

As demonstrated in Figures $7(\mathrm{a})$ and $7(\mathrm{~b})$, the protein levels of cleaved caspase- 3 were markedly increased $(p<0.01)$ in the $4 \mathrm{mg} / \mathrm{kg} \mathrm{Cu}$ treatment group at days 21 and 42 as well as in the 8 and $16 \mathrm{mg} / \mathrm{kg} \mathrm{Cu}$ treatment groups at day 42 in comparison to the control group. Intriguingly, the protein levels of cleaved caspase- 9 in the $8 \mathrm{mg} / \mathrm{kg} \mathrm{Cu}$ treatment group at days 21 and 42 as well as in the 4 and $16 \mathrm{mg} / \mathrm{kg} \mathrm{Cu}$ treatment groups at day 42 were increased $(p<0.05$ or $<0.01)$ compared to those in the control group. Besides, the protein levels of cleaved PARP were significantly increased $(p<0.01)$ in the 8 and $16 \mathrm{mg} / \mathrm{kg} \mathrm{Cu}$ treatment groups at days 21 and 42 when compared to the control group. In agreement with these protein expression patterns, the mRNA expression levels of caspase-3, caspase-9, and PARP were higher $(p<0.05$ or $<0.01)$ in the three $\mathrm{Cu}$ treatment groups at days 21 and 42 than in the control group (Figures 7(c) and 7(d)).

Furthermore, when compared with the control group, the protein levels of Bax, Bak, and Bim were markedly increased $(p<0.01)$ in the three $\mathrm{Cu}$ treatment groups at day 42 and those of Bim were increased $(p<0.01)$ in the 8 and $16 \mathrm{mg} / \mathrm{kg}$ $\mathrm{Cu}$ treatment groups at day 21 (Figures 8(a) and 8(b)). On the contrary, the protein levels of $\mathrm{Bcl}-2$ and $\mathrm{Bcl}-\mathrm{xL}$ were markedly decreased $(p<0.01)$ in the 8 and $16 \mathrm{mg} / \mathrm{kg} \mathrm{Cu}$ 


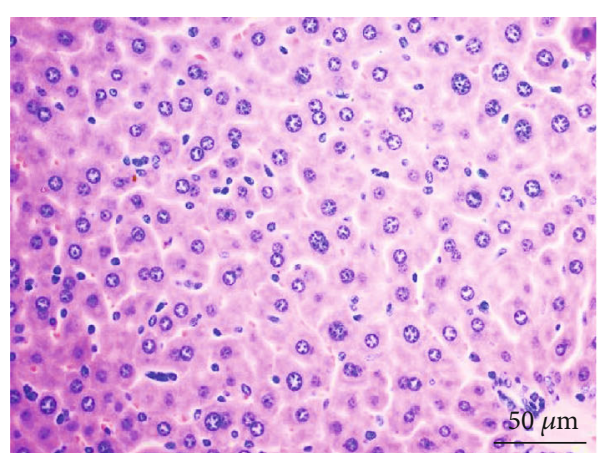

(A)

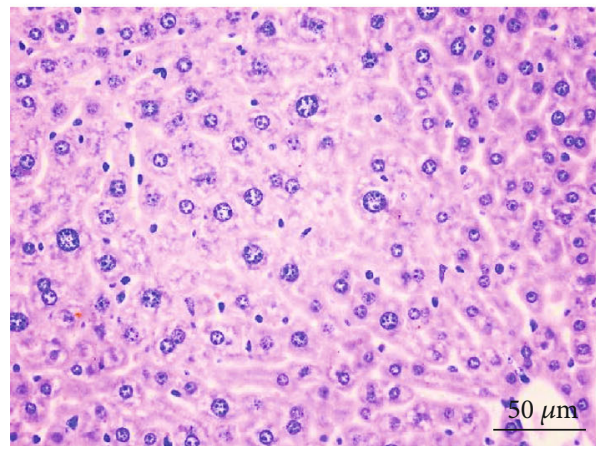

(C)

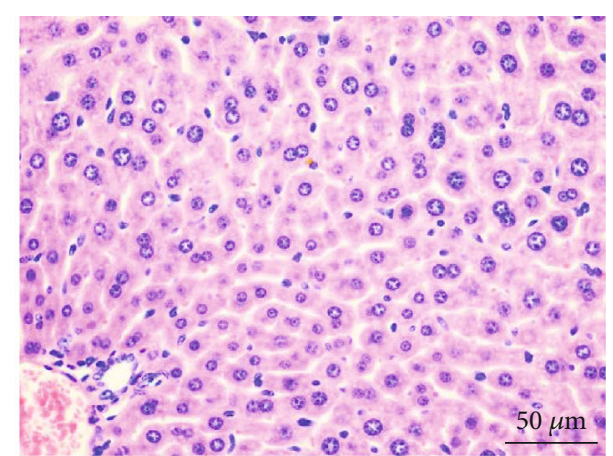

(B)

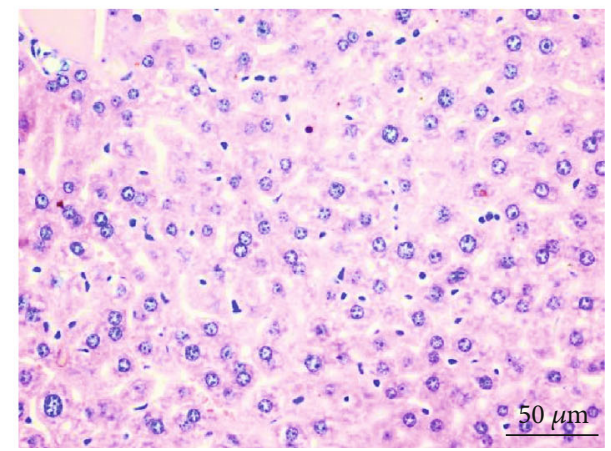

(D)

(a)

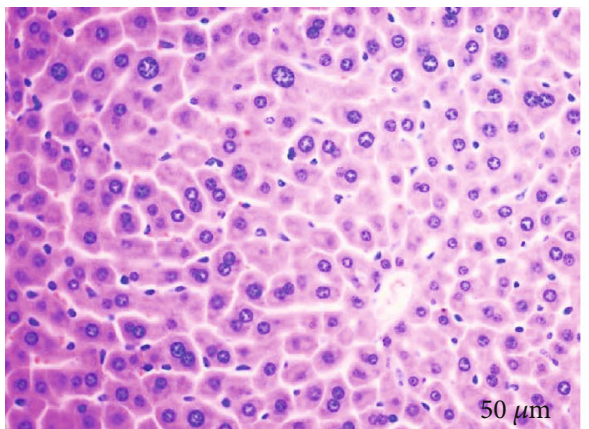

(A)

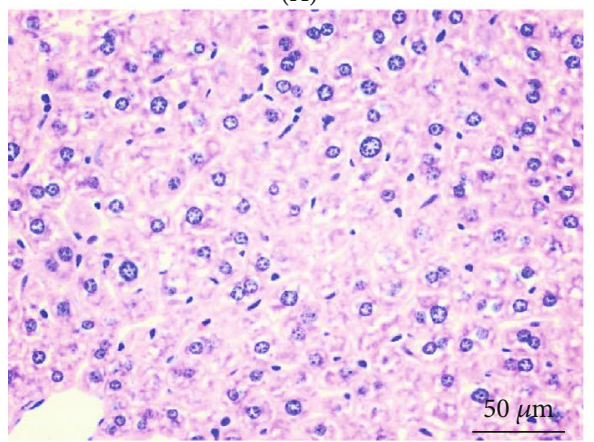

(C)

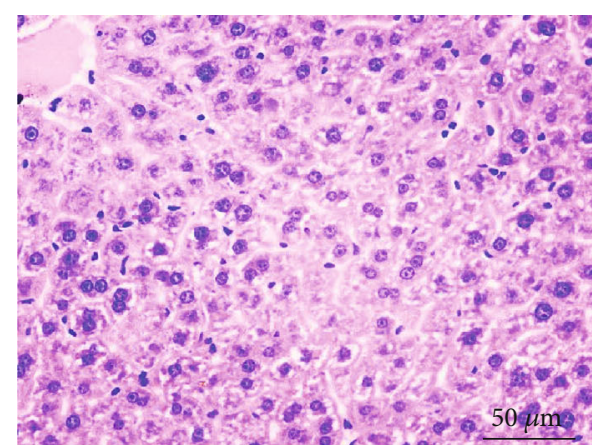

(B)

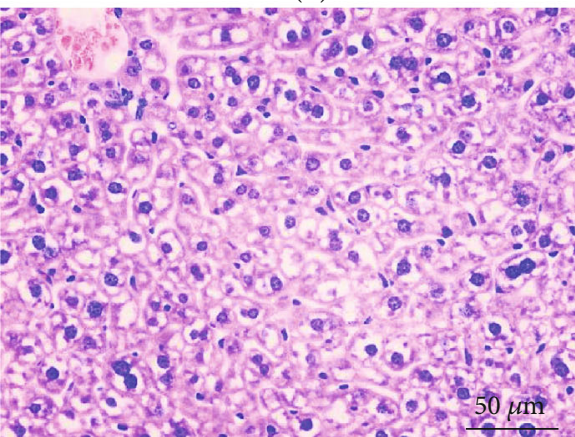

(D)

(b)

Figure 2

treatment groups at day 42 , and those of $\mathrm{Bcl}-2$ were also reduced $(p<0.01)$ in the $16 \mathrm{mg} / \mathrm{kg} \mathrm{Cu}$ treatment group at day 21 when compared to the control group (Figures 8 (a) and $8(\mathrm{~b}))$. As shown in Figures $8(\mathrm{c})$ and $8(\mathrm{~d})$, the mRNA expression levels of Bax and Bim in the three $\mathrm{Cu}$ treatment groups at days 21 and 42 were higher $(p<0.05$ or $<0.01)$ than those in the control group. The mRNA expression levels of Bak were significantly upregulated $(p<0.01)$ in the 4 and 

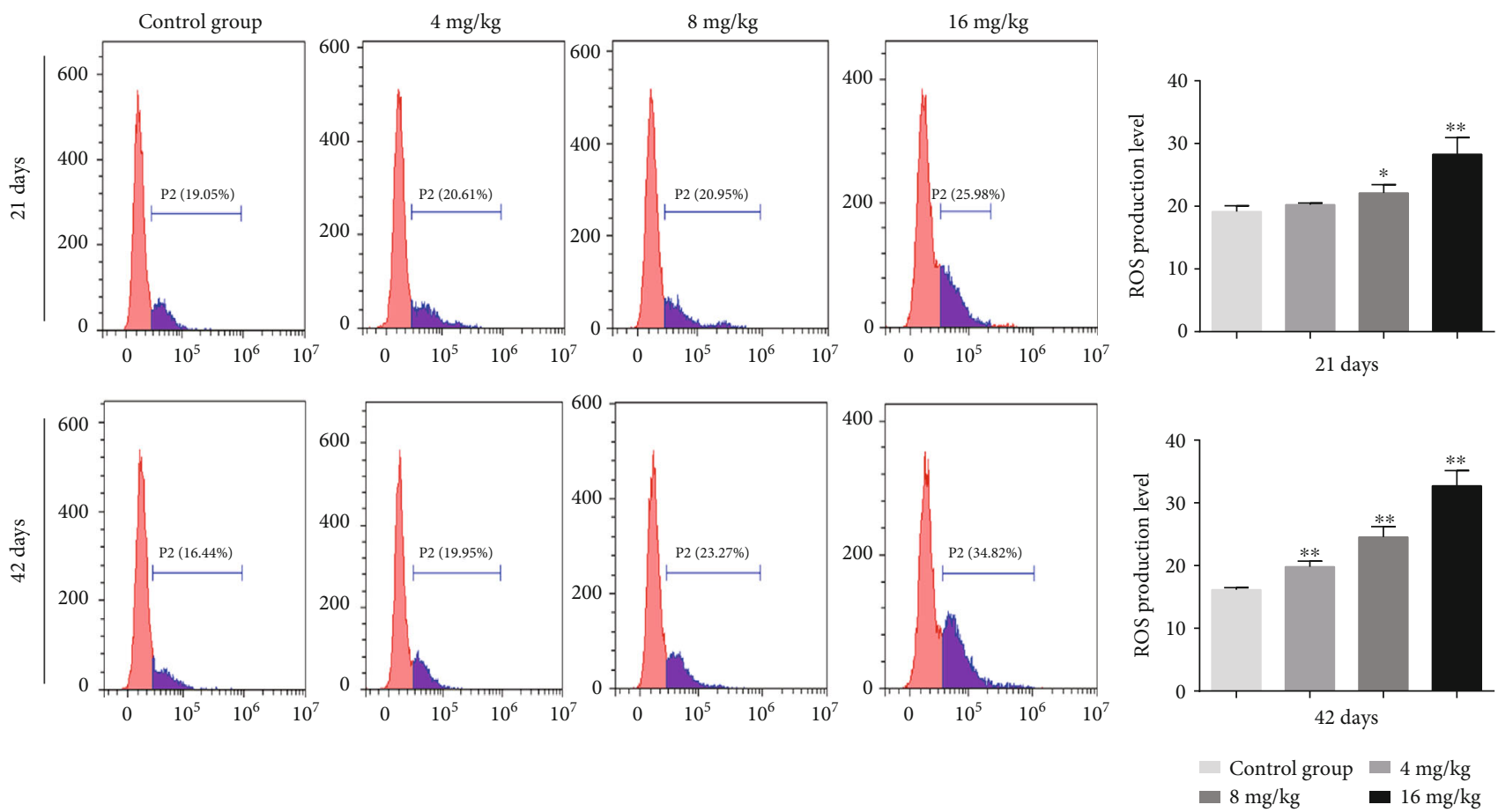

(a)
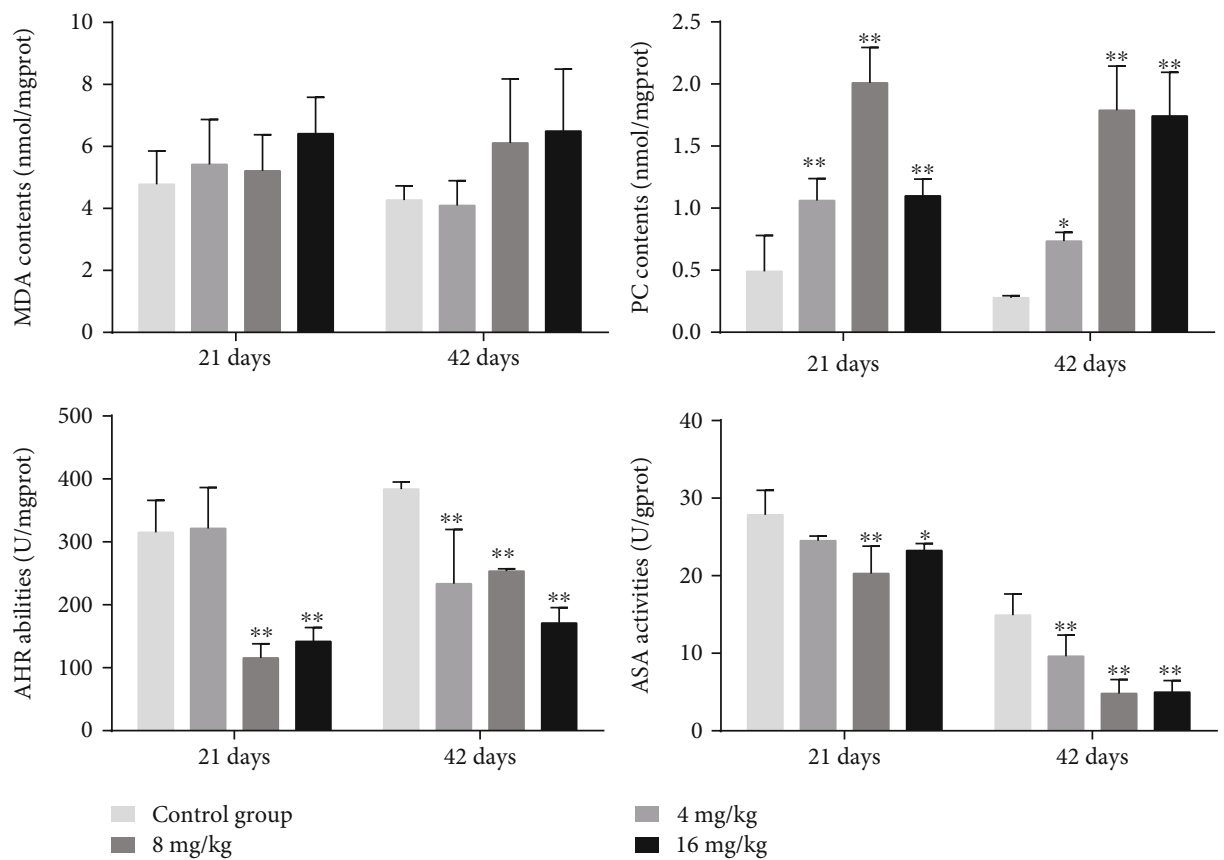

(b)

Figure 3

$16 \mathrm{mg} / \mathrm{kg} \mathrm{Cu}$ treatment groups at days 21 and 42 as well as in the $8 \mathrm{mg} / \mathrm{kg} \mathrm{Cu}$ treatment group at day 42 . In contrast, when compared with the control group, the mRNA expression levels of Bcl-2 and Bcl-xl were lower $(p<0.05$ or $<0.01)$ in the three $\mathrm{Cu}$ treatment groups at day 42 as well as in the $16 \mathrm{mg} / \mathrm{kg} \mathrm{Cu}$ treatment group at day 21 , but higher $(p<0.05$ or $<0.01)$ in the $4 \mathrm{mg} / \mathrm{kg} \mathrm{Cu}$ treatment group at day 21 (Figures $8(\mathrm{c})$ and $8(\mathrm{~d})$ ).
3.8. Changes in the Protein and mRNA Expression Levels of Apoptotic Parameters Associated with the Death Receptor Pathway in the Liver. As shown in Figures 9(a) and 9(b), the protein levels of TNF-R1 and FADD were increased $(p<0.05$ or $<0.01)$ in the three $\mathrm{Cu}$ treatment groups at day 42 and those of FADD were increased $(p<0.05$ or $<0.01)$ in the three $\mathrm{Cu}$ treatment groups at day 21, when compared to the control group. Moreover, the protein levels of TRADD 

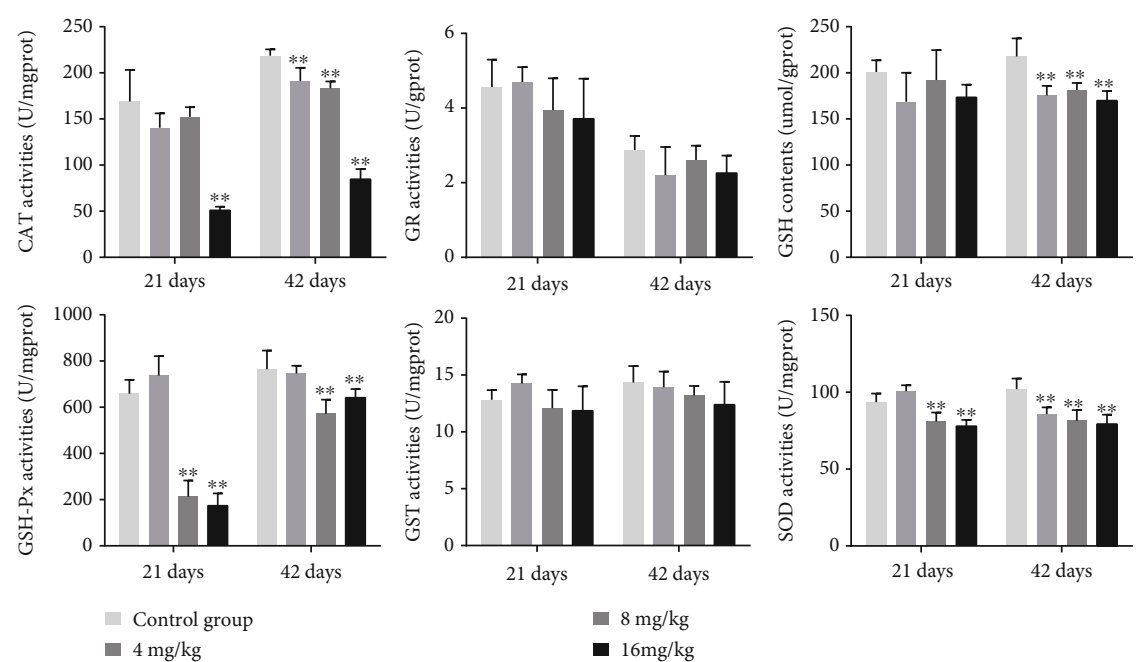

(a)
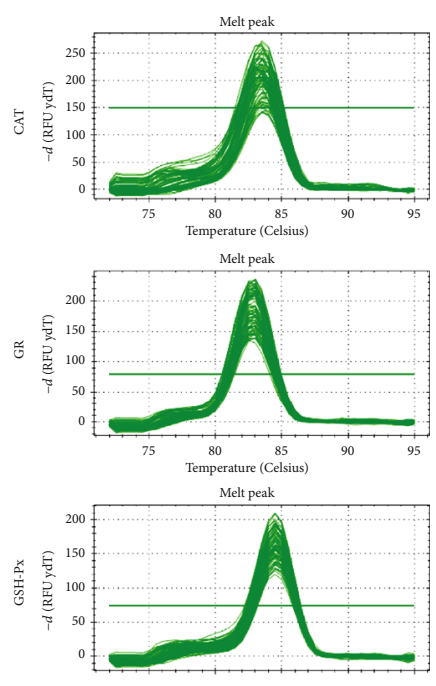

Melt peak
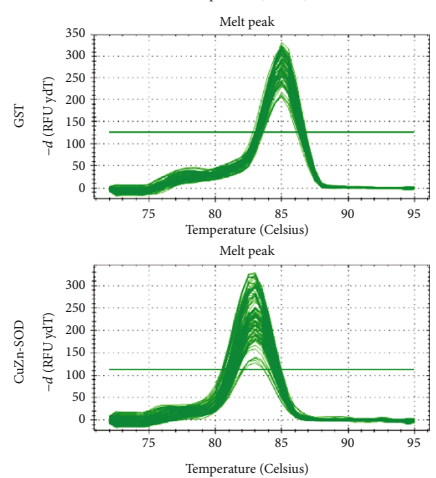

Melt peak

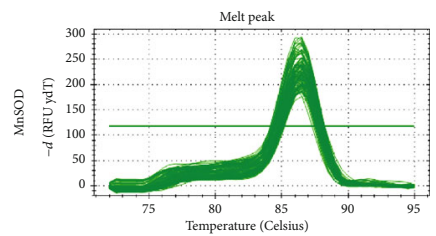

(b)
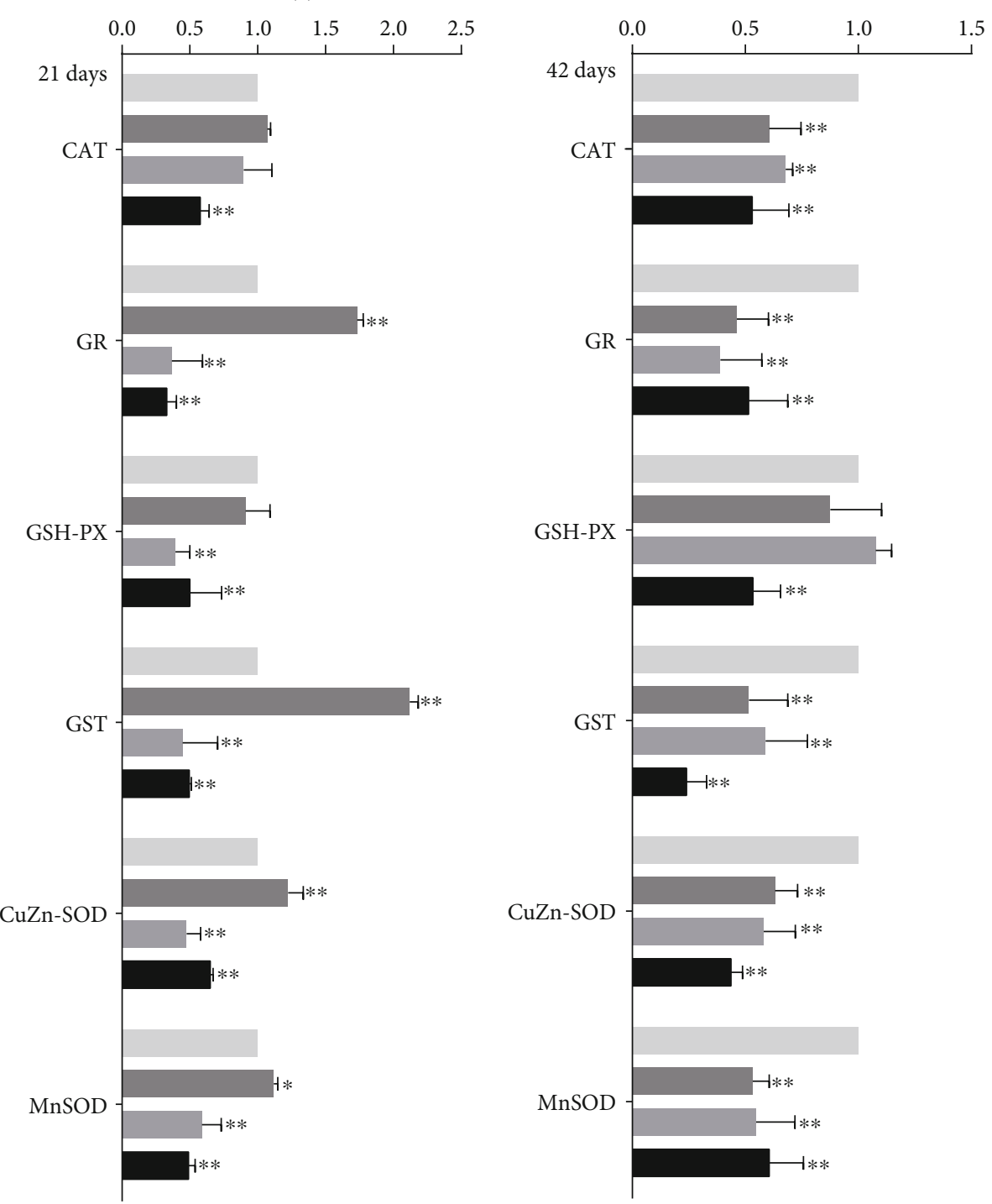

Controlgroup

$4 \mathrm{mg} / \mathrm{kg}$

$8 \mathrm{mg} / \mathrm{kg}$

$16 \mathrm{mg} / \mathrm{kg}$

(c)

Figure 4 


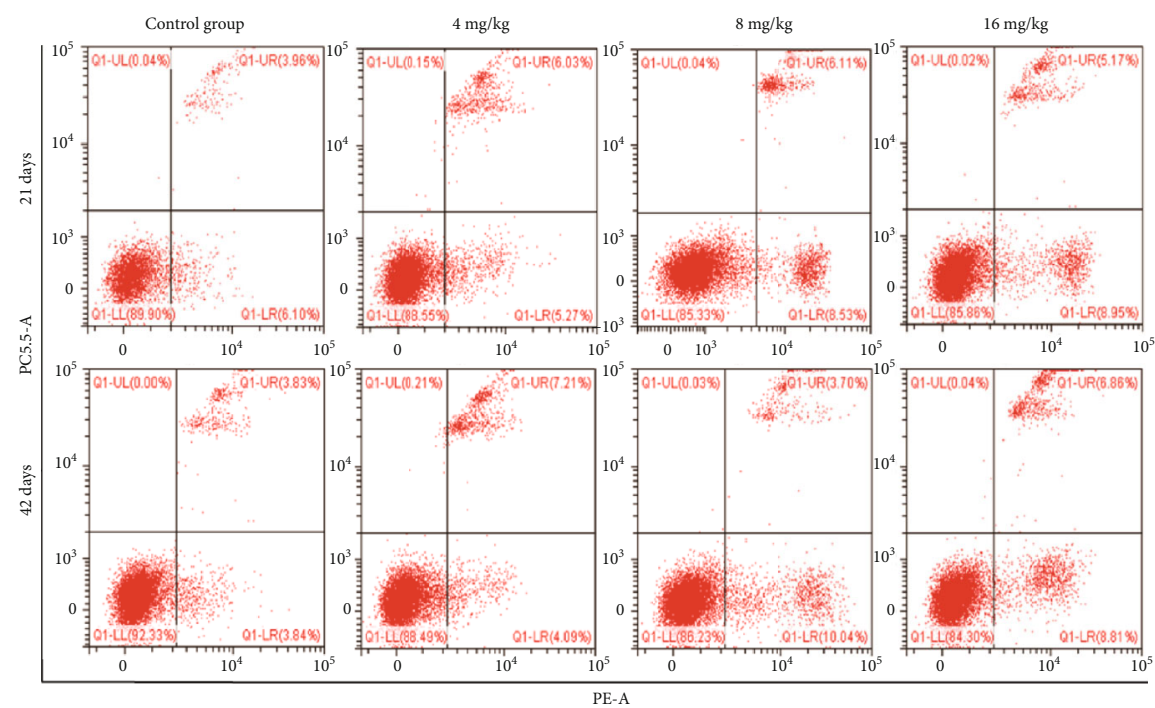

(a)

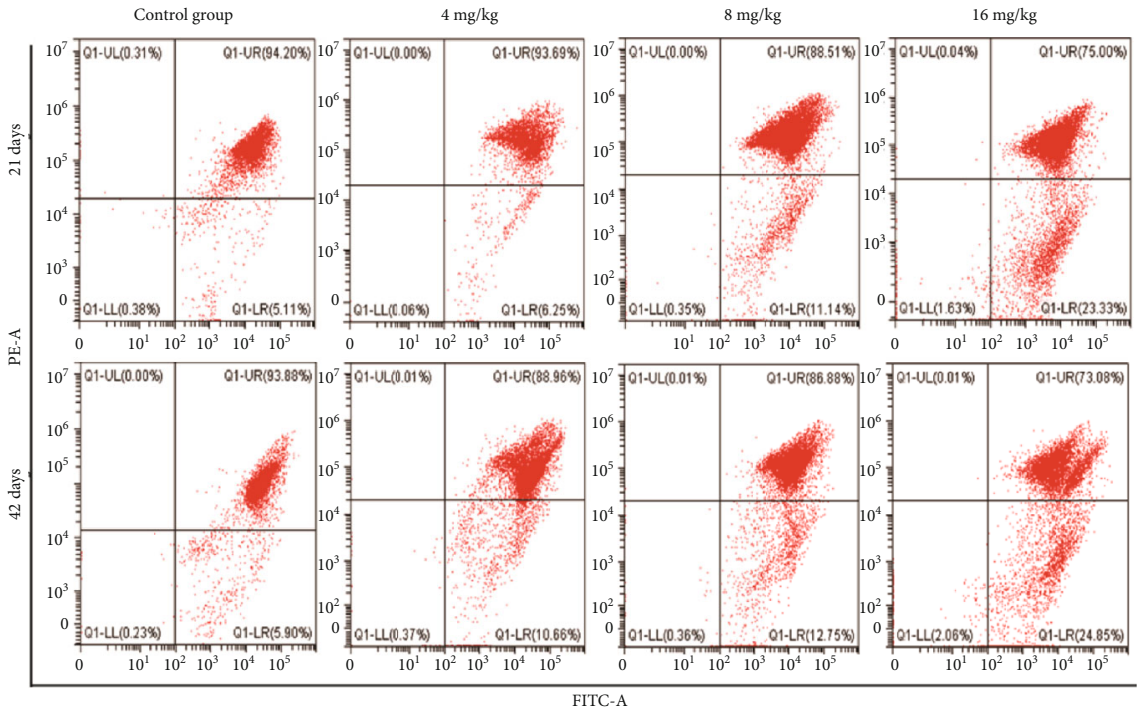

(b)

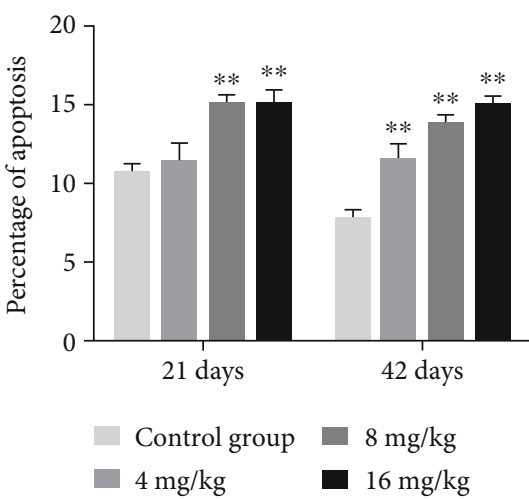

(c)

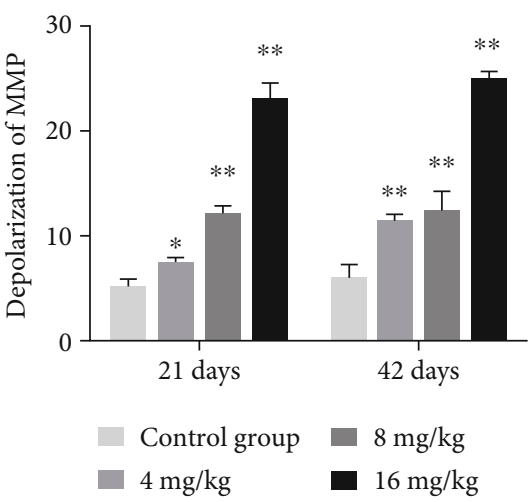

(d)

Figure 5: $\mathrm{Cu}$ induced apoptosis and depolarization of MMP in the liver at 21 and 42 days of experiment. (a) Apoptosis analyzed by flow cytometry. (b) Depolarization of MMP analyzed by flow cytometry. (c) Quantitation of percentage of total apoptotic cells. (d) Quantitation of depolarization of MMP. Data are presented as the means \pm standard deviation $(n=8) .{ }^{*} p<0.05$ and ${ }^{* *} p<0.01$, compared with the control group. 

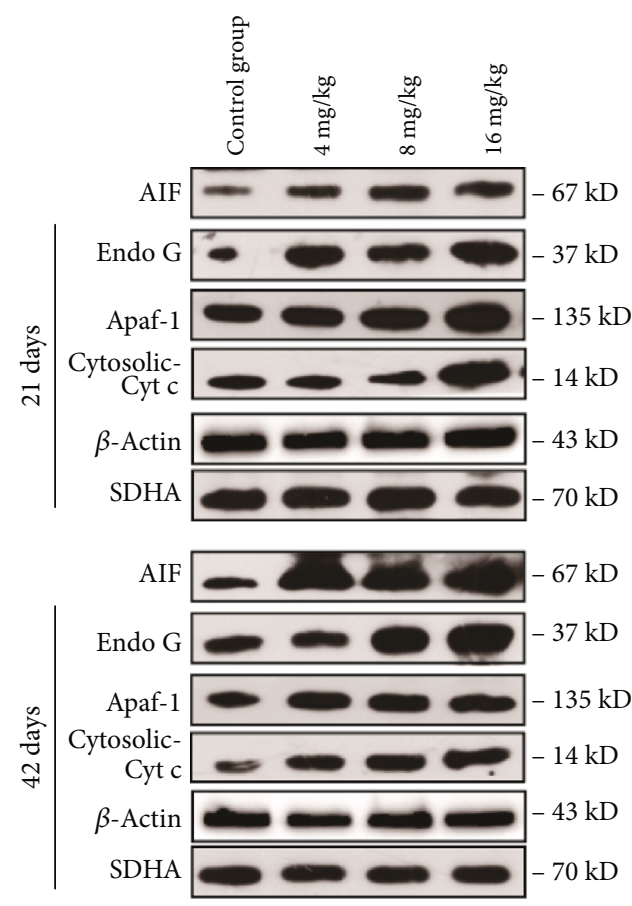

(a)

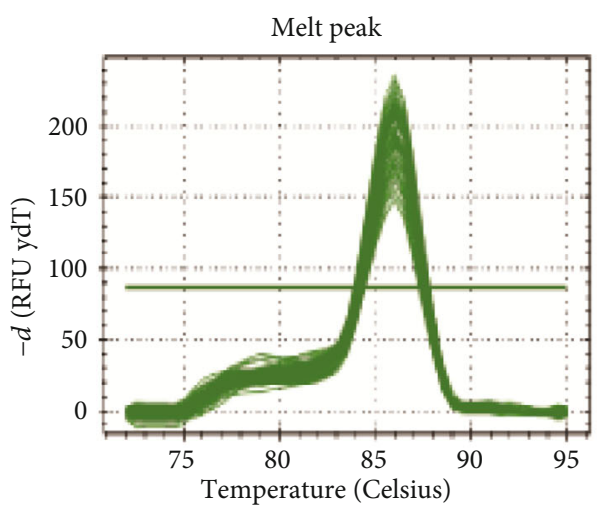

AIF

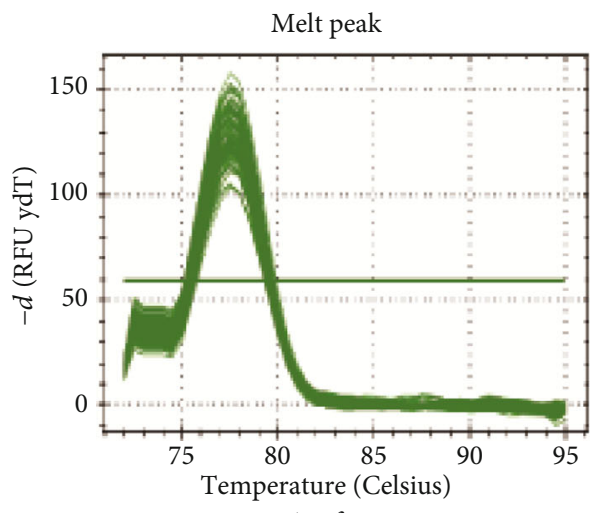

Apaf-1
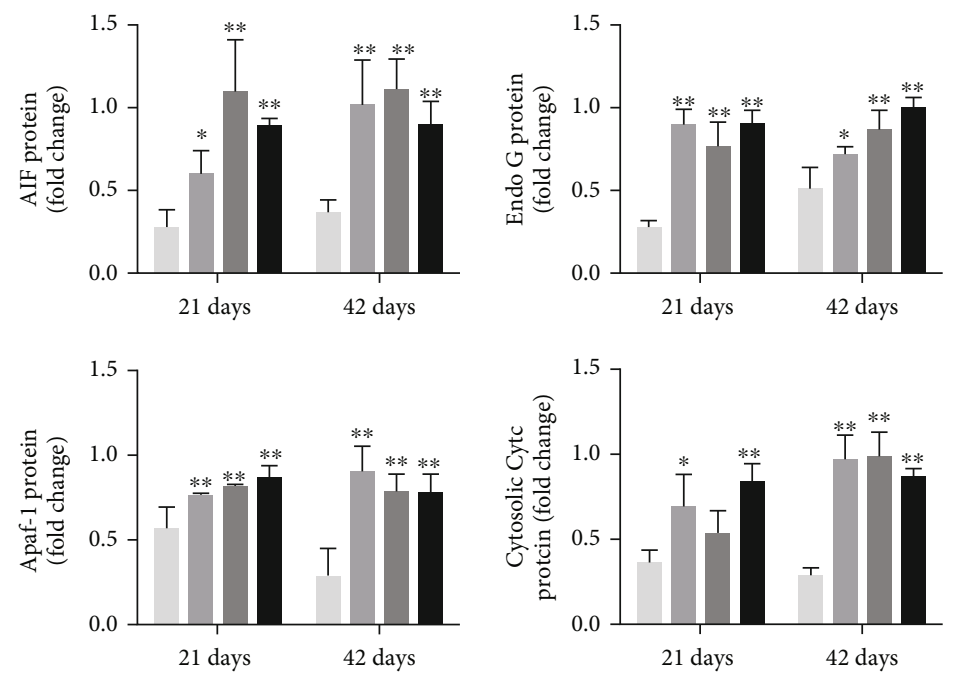

Control group
$\quad 8 \mathrm{mg} / \mathrm{kg}$

$4 \mathrm{mg} / \mathrm{kg}$

- $16 \mathrm{mg} / \mathrm{kg}$

(b)

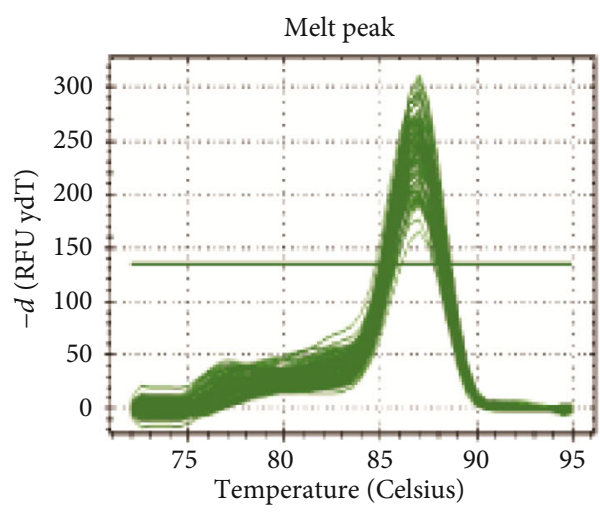

Endo G

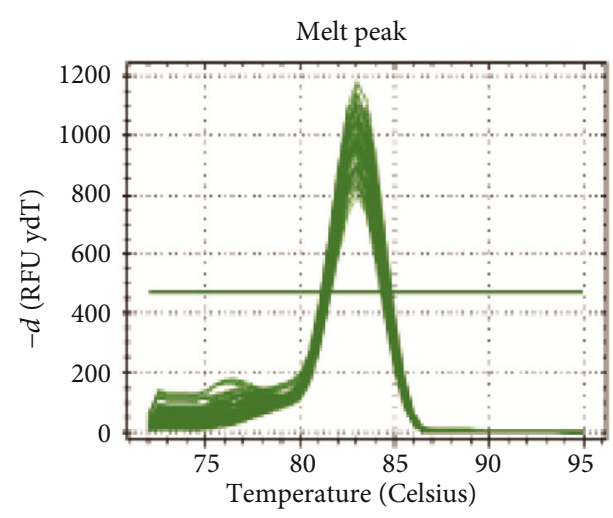

Cyt c

(c)

Figure 6: Continued. 

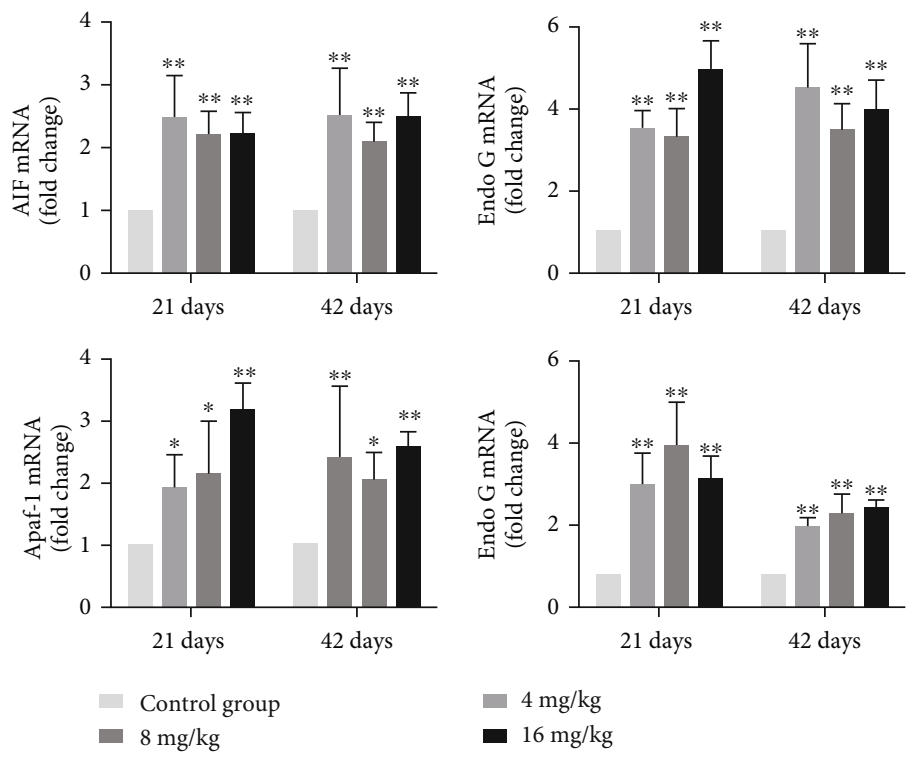

(d)

FIGURE 6: Changes of protein and mRNA expression levels of AIF, Endo G, Apaf-1, and Cyt c in the liver at 21 and 42 days of experiment. (a) The western blot assay of AIF, Endo G, Apaf-1, and Cyt c. (b) The relative protein expression levels of AIF, Endo G, Apaf-1, and Cyt c. (c) The melting curve analysis of AIF, Endo G, Apaf-1, and Cyt c. (d) The relative mRNA expression levels of AIF, Endo G, Apaf-1, and Cyt c. Data are presented as the means \pm standard deviation $(n=8) .{ }^{*} p<0.05$ and ${ }^{* *} p<0.01$, compared with the control group.

and cleaved caspase- 8 in the 4 and $8 \mathrm{mg} / \mathrm{kg} \mathrm{Cu}$ treatment groups at day 42 and in the $16 \mathrm{mg} / \mathrm{kg} \mathrm{Cu}$ treatment group at days 21 and 42 were higher $(p<0.05$ or $<0.01)$ than those in the control group. Similar to these protein expression data, the mRNA expression levels of TNF-R1, FADD, TRADD, and caspase- 8 were significantly increased $(p<0.01)$ in the three $\mathrm{Cu}$ treatment groups at days 21 and 42 when compared to the control group (Figures 9(c) and 9(d)).

\section{Discussion}

$\mathrm{Cu}$ is required to support numerous biological activities, but it can exert cytotoxic effects when its concentration exceeds the body tolerance. Overexposure to $\mathrm{Cu}$ may produce some detrimental effects in the basal ganglia of human [28] and in the kidney [20], spleen, and thymus [29] in mice. Hepatocytes are regarded as one of the main target cells for $\mathrm{Cu}$ toxicity. Several studies have shown that $\mathrm{Cu}$ can induce oxidative stress, mitochondrial dysfunction, and apoptosis in hepatocytes [30, 31]. However, the underlying mechanism remains largely unclear. The present study investigated $\mathrm{Cu}$-induced hepatic apoptosis and oxidative stress as well as their relationship. Additionally, our findings also indicated that $\mathrm{Cu}$ could induce apoptosis through the mitochondrial apoptotic and death receptor signaling pathway in the mouse liver.

To establish an animal model of $\mathrm{Cu}$-induced hepatic damage, the experimental mice were treated with graded levels of $\mathrm{Cu}(0,4,8$, and $16 \mathrm{mg} / \mathrm{kg}$, respectively) for 42 days. The dose of $\mathrm{Cu}$ used in this study was based on the median lethal dose value (LD50, $245.47 \mathrm{mg} / \mathrm{kg}$ ) obtained from an acute oral toxicity study. Body weight is a basic quality factor of the health state. In this study, the body weight was signif- icantly decreased under excessive $\mathrm{Cu}$ exposure, indicating that excessive intake of $\mathrm{Cu}$ exerted a toxic effect on the mice (Figure 1(a)). Hepatic $\mathrm{Cu}$ concentration was markedly increased in the $16 \mathrm{mg} / \mathrm{kg} \mathrm{Cu}$ treatment group at 42 days of the experiment (Figure 1(b)). Also, the hepatic growth index was decreased in high $\mathrm{Cu}$ treatment groups, suggesting that $\mathrm{Cu}$ overload could suppress hepatic development (Figure 1(d)). Besides, our results clearly demonstrated that the high doses of $\mathrm{Cu}$ could cause histopathological lesions, such as degeneration and necrosis, in the mouse liver at days 21 and 42 in a dose- and time-dependent manner.

Several mechanisms have been proposed to explain the cellular toxicity of $\mathrm{Cu}$ exposure. One of the most accepted is the propensity of stimulating ROS production, which results in oxidative stress [32]. In the present study, the levels of ROS were significantly increased upon $\mathrm{Cu}$ exposure in a time- and dose-dependent manner (Figure 3(a)). Excessive ROS production can oxidize cell components such as protein, leading to protein oxidation [33]. PC are the representative products of protein oxidation [27]. Moreover, our results clearly demonstrated that the contents of $\mathrm{PC}$ were increased in the three $\mathrm{Cu}$ treatment groups, which are consistent with the overproduction of ROS. Besides, the abilities of ASA and AHR are often used to assess the total capacity of scavenging superoxide anion and hydroxyl radical, respectively, which represent the portion of ROS $[34,35]$. In the present study, the abilities of ASA and AHR were decreased in the three $\mathrm{Cu}$ treatment groups when compared to the control group, suggesting that the capacity of the liver to scavenge ROS products is reduced after $\mathrm{Cu}$ exposure. The imbalance between ROS and the antioxidant defense system can lead to oxidative stress. Thus, we further examined the effects of $\mathrm{Cu}$ on the activities 

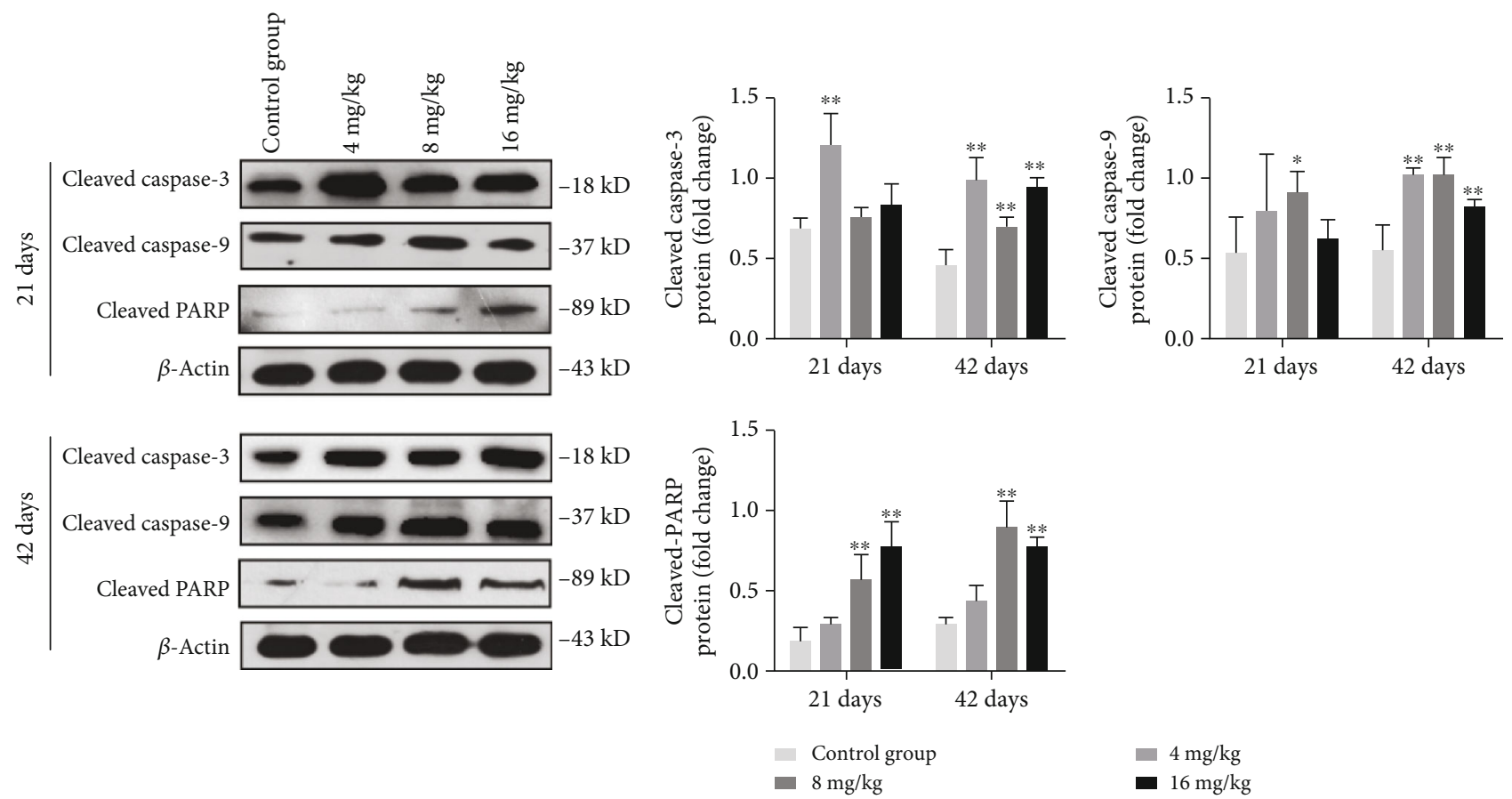

(a)
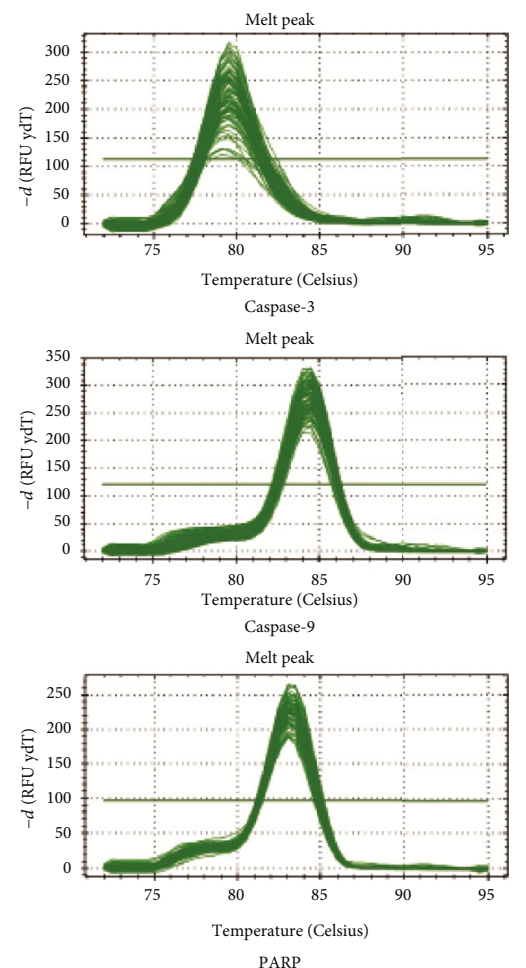

(c)
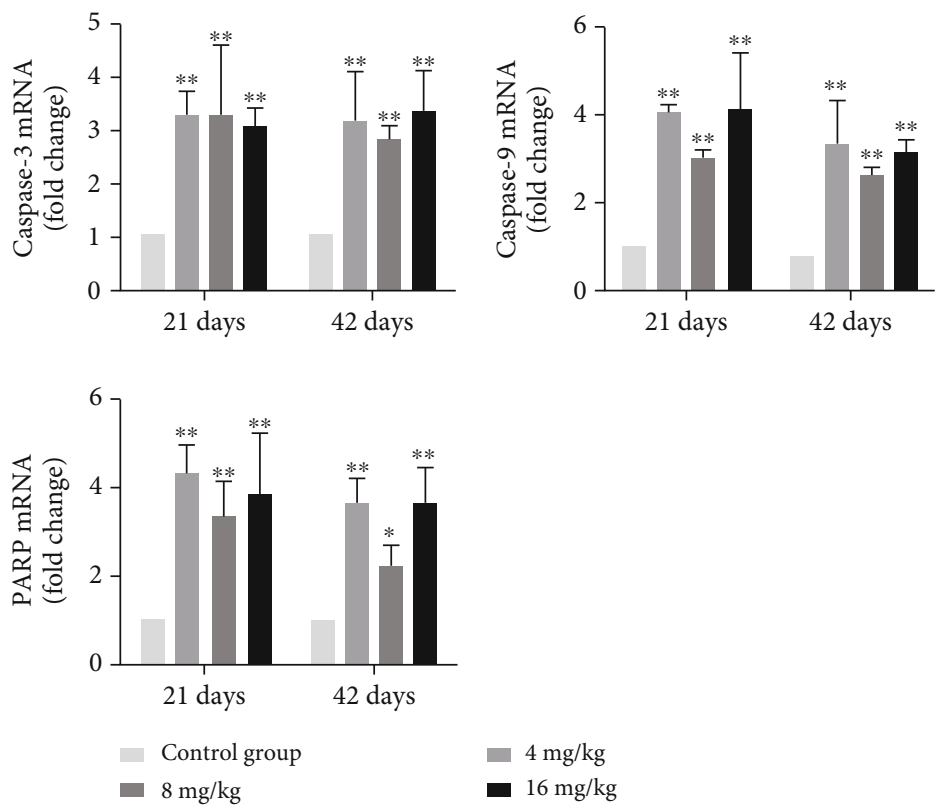

(d)

FIGURE 7: Changes of protein and mRNA expression levels of caspase-3, caspase-9, and PARP in the liver at 21 and 42 days of experiment. (a) The western blot assay of cleaved caspase-3, cleaved caspase-9, and cleaved PARP. (b) The relative protein expression levels of cleaved caspase-3, cleaved caspase-9, and cleaved PARP. (c) The melting curve analysis of caspase-3, caspase-9, and PARP. (d) The relative mRNA expression levels of caspase-3, caspase-9, and PARP. Data are presented as the means \pm standard deviation $(n=8)$. ${ }^{*} p<0.05$ and ${ }^{* *} p<0.01$, compared with the control group. 

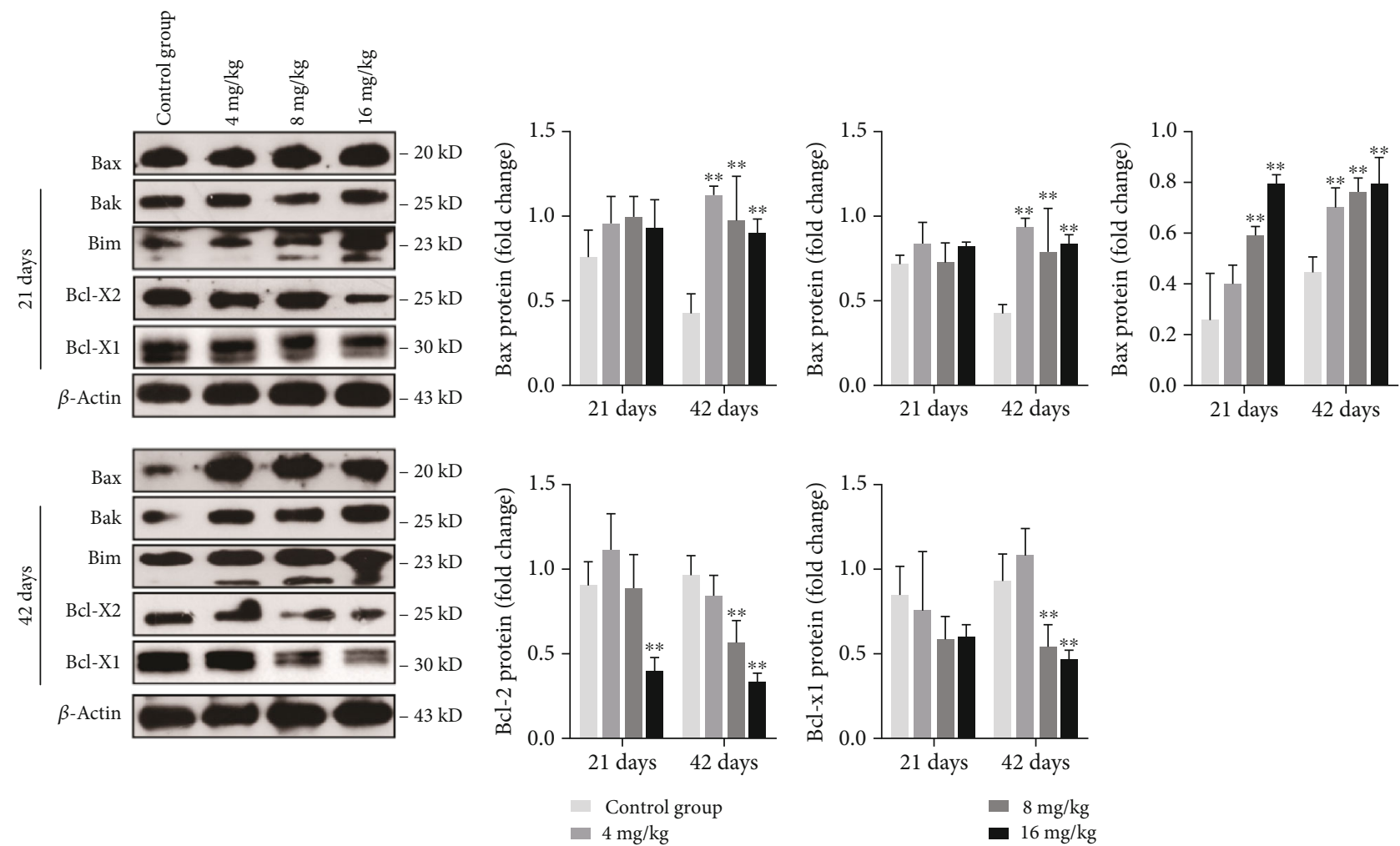

(a)

(b)
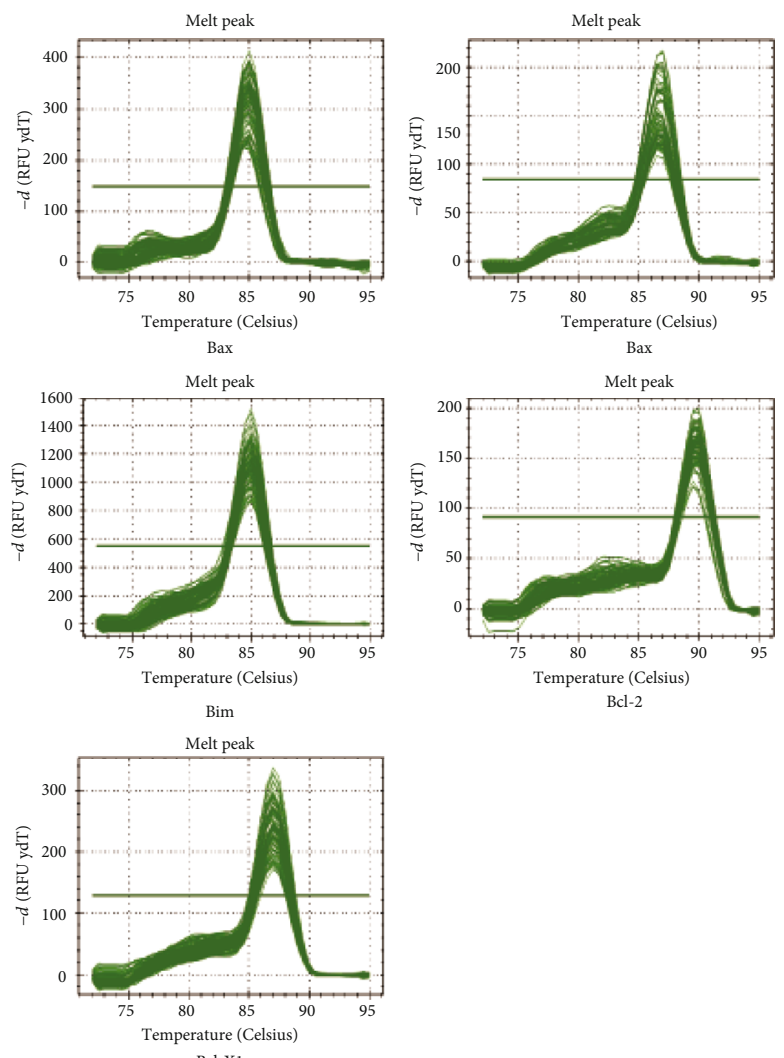

(c)

Figure 8: Continued. 

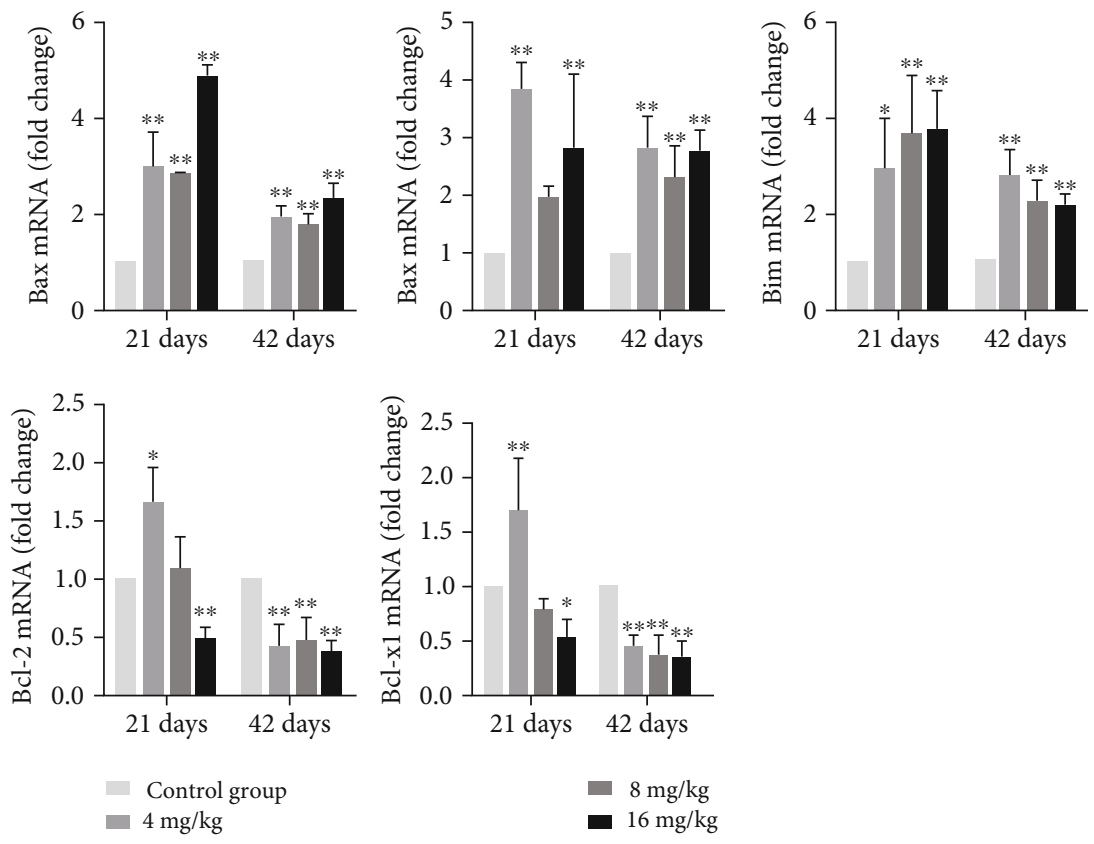

(d)

FIGURE 8: Changes of protein and mRNA expression levels of Bax, Bak, Bim, Bcl-2, and Bcl-xl in the liver at 21 and 42 days of experiment. (a) The western blot assay of Bax, Bak, Bim, Bcl-2, and Bcl-xl. (b) The relative protein expression levels of Bax, Bak, Bim, Bcl-2, and Bcl-xl. (c) The melting curve analysis of Bax, Bak, Bim, Bcl-2, and Bcl-xl. (d) The relative mRNA expression levels of Bax, Bak, Bim, Bcl-2, and Bcl-xl. Data are presented as the means \pm standard deviation $(n=8) .{ }^{*} p<0.05$ and ${ }^{* *} p<0.01$, compared with the control group.

of antioxidant enzymes and contents of nonenzymatic antioxidants in the mouse liver.

The results of this study showed that $\mathrm{Cu}$ decreased the activities of CAT, GSH-Px, and SOD, as well as GSH contents in the liver at different degrees (Figure 4(a)), which are in line with our earlier findings on the effects of $\mathrm{Cu}$ on antioxidant enzymes $[5,36]$. CAT and SOD are parts of free radicalscavenging enzymes that ameliorate the damaging effects of ROS by converting them into oxygen, which is later converted into water [37]. The decreased activities of CAT and SOD can be used to indicate the accumulation of superoxide radicals and/or hydroxyl radicals in the liver. GSH, as a nonenzymatic scavenger, can scavenge a wide variety of reactive species [38]. GSH-Px works together with CAT to scavenge excess lipid peroxide and hydrogen, which is helpful for eliminating peroxide during the reaction between $\mathrm{GSH}$ and $\mathrm{H}_{2} \mathrm{O}_{2}$ [27]. Therefore, the low activities of GSH-Px are related to the accumulation of free radicals and/or depletion of GSH. To further explore the molecular basis of the changes in antioxidant enzyme activities, the mRNA expression levels of CAT, GR, GSH-Px, GST, CuZn-SOD, and MnSOD were detected in this study. The results showed that the mRNA expression levels of these antioxidant enzymes were decreased in the three $\mathrm{Cu}$ treatment groups at different degrees, which are consistent with the reduction of their activities. All the above results clearly indicated that $\mathrm{Cu}$ not only promoted ROS production but also inhibited the activities and mRNA expression of antioxidant enzymes in the liver. Thus, the imbalance between ROS production and antioxidative function could lead to oxidative stress, which in turn contributes to the occurrence of hepatic apoptosis.
It is well known that both ROS and oxidative stress can serve as the inducer of apoptosis [39]. After entering into the hepatocytes, a portion of $\mathrm{Cu}$ is being transported to the mitochondria for cytochrome c oxidase incorporation [40]. High levels of $\mathrm{Cu}$ can induce the overproduction of ROS [3], which further impairs mitochondrial electron transport and results in mitochondrial dysfunction that is linked to the occurrence of apoptosis [41]. In this study, the rates of apoptotic hepatocytes were higher in the three $\mathrm{Cu}$ treatment groups than in the control group. The significant depolarization of MMP was also observed in the three $\mathrm{Cu}$ treatment groups when compared to the control group. The changes in mitochondrial outer membrane permeabilization can cause the release of Cyt c, AIF, and Endo G from the mitochondrion into the cytosol, leading to caspase activation and apoptosis [42, 43]. Cytosolic Cyt c binds to Apaf- 1 and procaspase-9 to form an apoptosome, thus resulting in caspase- 9 activation $[44,45]$. The activated caspase- 9 cleaves and activates the downstream executioner caspase- 3 , which ultimately triggers PARP cleavage and apoptosis [43]. In the present study, the upregulated mRNA and protein expression levels of cytosolic Cyt c, Apaf-1, cleaved caspase3 and caspase-9, and cleaved PARP were observed. Santos and colleagues [46] have reported that $\mathrm{Cu}$ induces apoptosis in Hep-G2 cells by altering the expression of caspase- 3 , caspase-8, caspase-9, AIF, and p53. Hosseini and coworkers [42] have also found that $\mathrm{Cu}$-induced liver apoptosis is the consequence of its disruptive effect on mitochondrial membrane permeability in hepatocytes caused by $\mathrm{Cu}$-induced ROS formation and Cyt c expulsion. In the present work, we also observed the increased expression levels of AIF and 

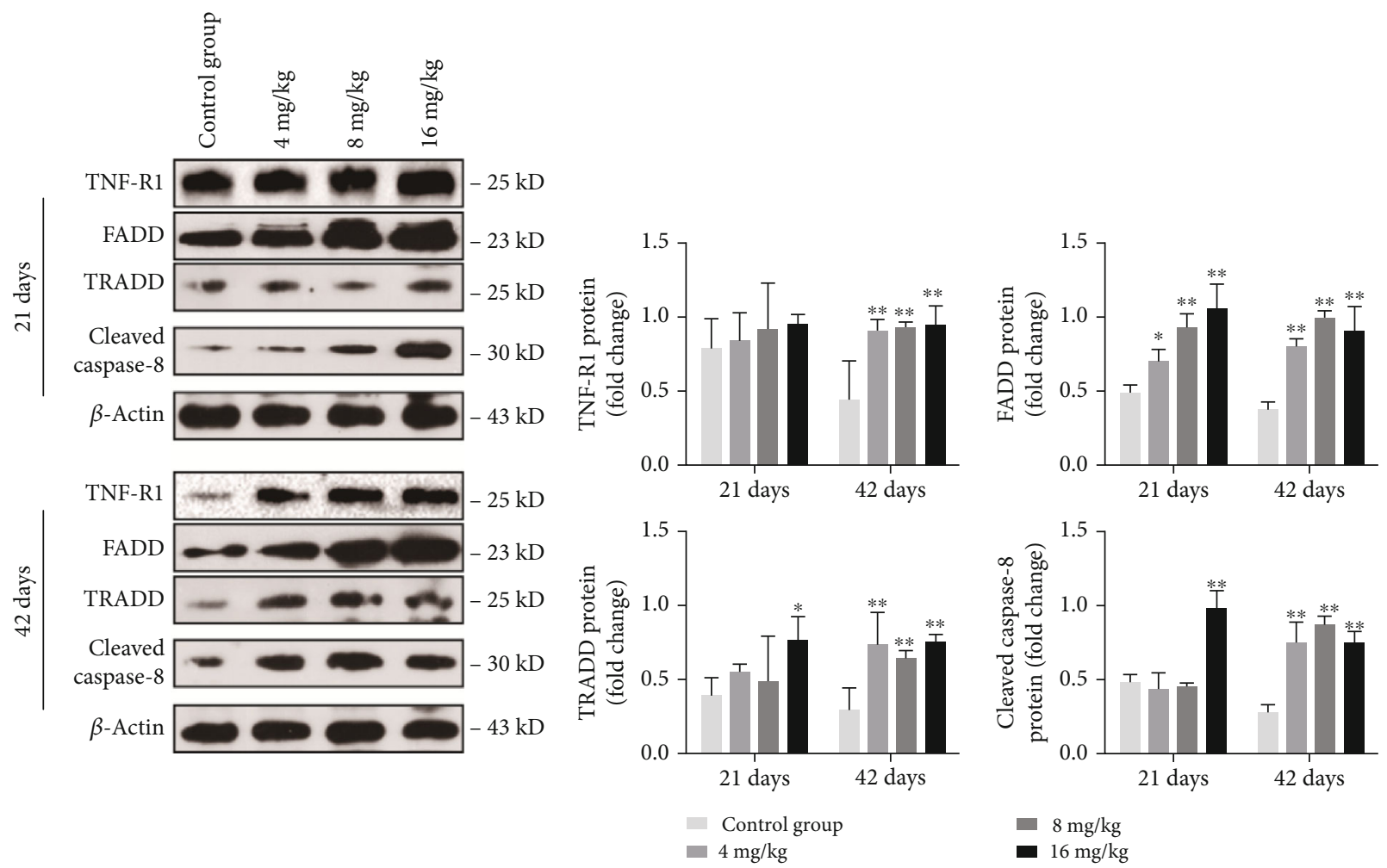

(a)

(b)
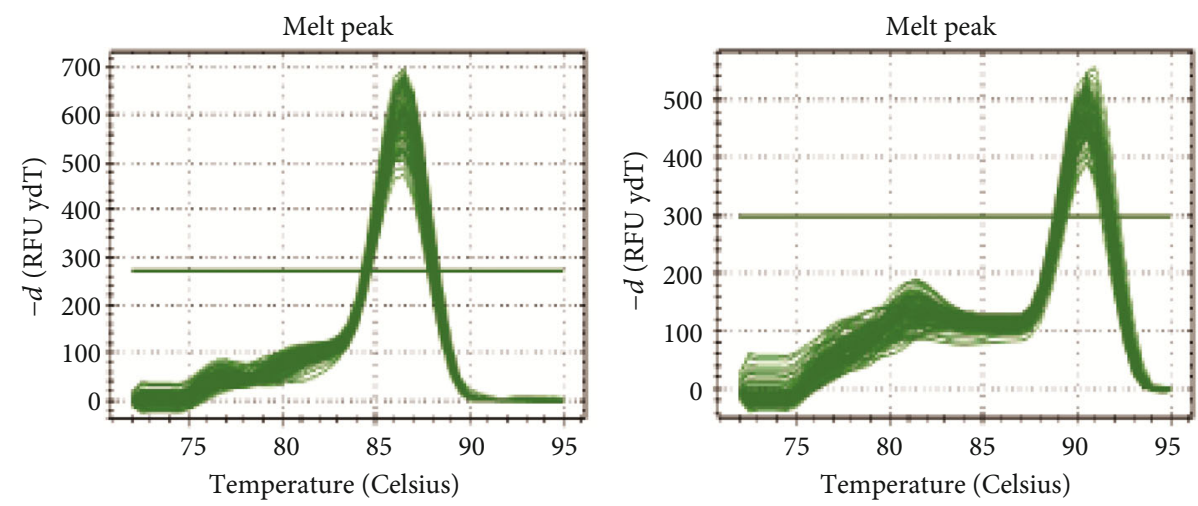

TNF-R1
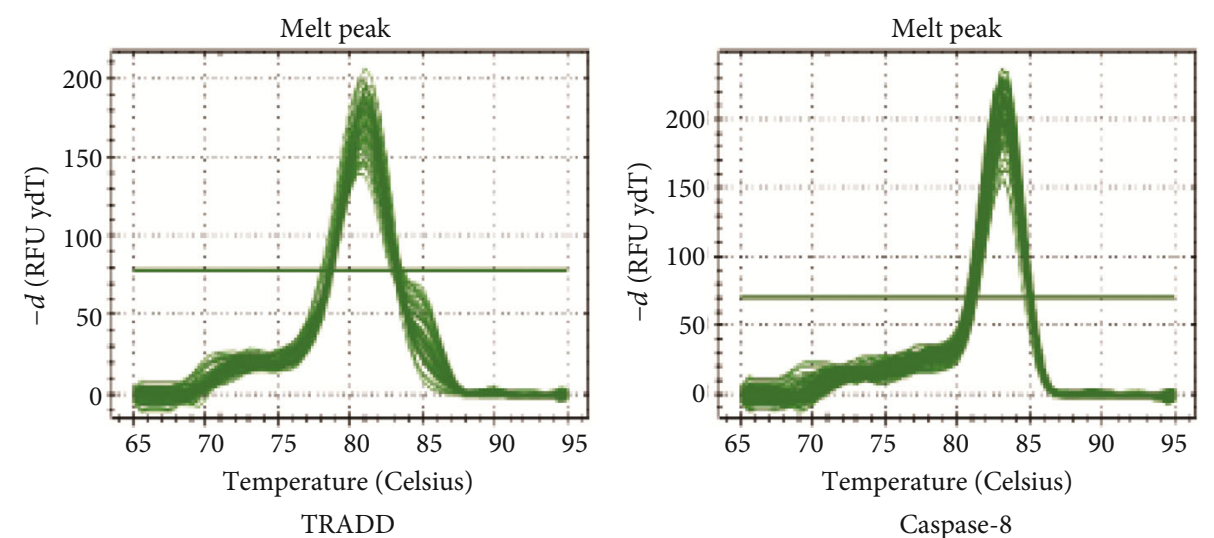

(c)

Figure 9: Continued. 

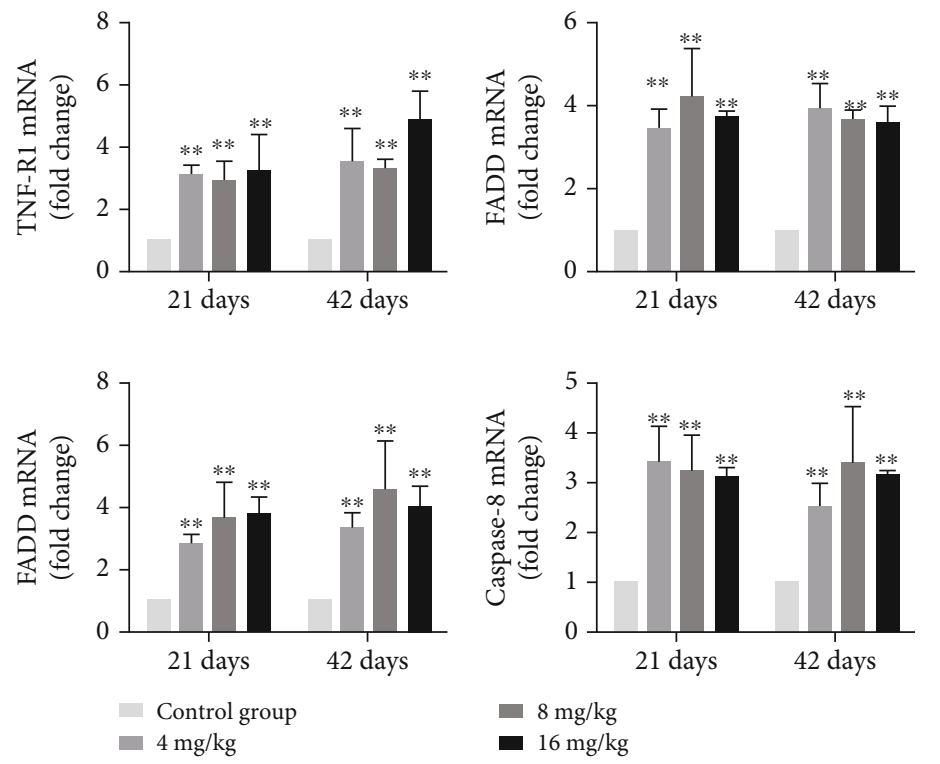

(d)

Figure 9: Changes of protein and mRNA expression levels of TNF-R1, FADD, TRADD, and caspase- 8 in the liver at 21 and 42 days of experiment. (a) The western blot assay of TNF-R1, FADD, TRADD, and cleaved caspase-8. (b) The relative protein expression levels of TNF-R1, FADD, TRADD, and cleaved caspase-8. (c) The melting curve analysis of TNF-R1, FADD, TRADD, and caspase-8. (d) The relative mRNA expression levels of TNF-R1, FADD, TRADD, and caspase-8. Data are presented as the means \pm standard deviation $(n=8)$. ${ }^{*} p<0.05$ and ${ }^{* *} p<0.01$, compared with the control group.

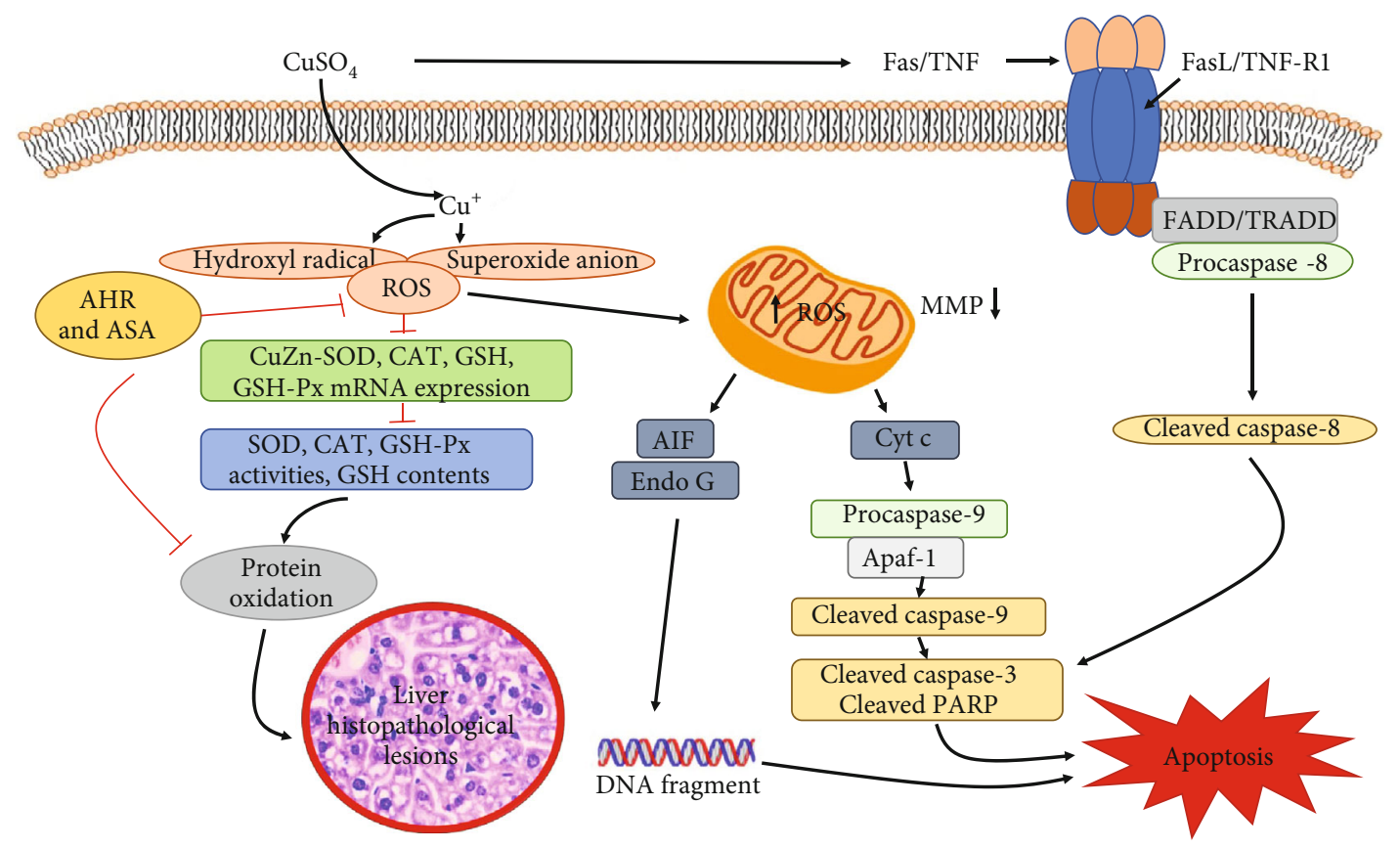

FIGURE 10

Endo G. It is noteworthy to mention that AIF and Endo G can translocate into the nucleus to cause DNA fragmentation and apoptosis via the caspase-independent mitochondrial pathway after MMP depolarization [47].

In addition, we found that $\mathrm{Cu}$ exposure increased the mRNA and protein expression levels of Bax, Bak, and Bim and decreased those of Bcl-2 and Bcl-xl. It is worth noting that Bax, Bak, and Bim belong to the proapoptotic Bcl-2 protein family. When apoptosis is initiated, Bim, as a $\mathrm{BH} 3$-only protein, can transfer into the mitochondrial outer membrane, promote the release of Cyt c and Endo G [48], and directly induce the conformational changes of Bax and 
Bak, which in turn mediate Cyt c efflux [49]. Therefore, the increased expression levels of Bim, Bax, and Bak corresponded to those of cytosolic Cyt $\mathrm{c}$ and Endo G in this study. Nevertheless, the antiapoptotic $\mathrm{Bcl}-2$ and $\mathrm{Bcl}-\mathrm{xl}$ have been reported to inhibit apoptosis by binding to Bax or Bak [50], thereby preventing the release of Cyt $\mathrm{c}$ and subsequent caspase activation [49]. Kawakami and colleagues [51] have found that a high intake of $\mathrm{Cu}$ can induce apoptosis via increasing the expression levels of Bax, Bad, caspase-3, Cyt c, and caspase-9 in PC12 cells. Chan and coworkers [52] have also observed that $\mathrm{Cu}$-induced apoptosis is often accompanied by the increased expression levels of Bax and Bak as well as decreased expression level of $\mathrm{Bcl}-2$ in neuroblastoma cells.

Furthermore, we found that excess $\mathrm{Cu}$ exposure increased the mRNA and protein expression levels of TNF-R1, FADD, TRADD, and caspase-8, which represent the important members in the death receptor signaling pathway. TNF-R1, as the receptor of TNF- $\alpha$, plays an important role in apoptosis induction [53]. Following the combination of ligands and receptors, FADD and TRADD adaptor proteins are being recruited, which then initiate the formation of deathinducing signaling molecules and further activate caspase-8 (a central mediator of the death receptor signaling pathway) [54]. The activated caspase- 8 catalyzes the proteolysis of caspase- 3 and drives the cascade reactions of downstream signaling molecules [25]. All the above findings clearly revealed that the TNF-R1 signaling pathway was involved in $\mathrm{Cu}$-induced hepatic apoptosis.

\section{Conclusion}

The results of this study demonstrate that exposure to excess $\mathrm{Cu}$ can induce hepatic oxidative damage by increasing the levels of ROS and PC, suppressing the ability to scavenge free radical and reducing the mRNA levels and activities of antioxidant enzymes, which in turn leads to hepatic lesions. The increased levels of ROS induced by $\mathrm{Cu}$ can impair mitochondrial membrane permeability, resulting in the activation of the mitochondrial apoptotic pathway and hepatic apoptosis. Additionally, it has been found that the TNF-R1 signaling pathway is involved in $\mathrm{Cu}$-induced apoptotic cell death in the mouse liver (Figure 10).

\section{Data Availability}

The data used to support the findings of this study are included within the article.

\section{Conflicts of Interest}

The authors declare that there are no conflicts of interest.

\section{Authors' Contributions}

H. Liu, H. Guo, and H. Cui designed the experiments. H. Liu, H. Guo, and Z. Jian carried out the experiments. H. Liu, H. Guo, Z. Jian, J. Fang, Z. Zuo, J. Deng, Y. Li, X. Wang, and L. Zhao analyzed and interpreted the data. H. Liu, H. Guo, Z. Jian, and H. Cui wrote and revised the manuscript. Huan
Liu, Hongrui Guo, and Zhijie Jian contributed equally to this work.

\section{Acknowledgments}

This research was supported by the Program for Changjiang Scholars and the University Innovative Research Team (IRT 0848) and the Shuangzhi project of Sichuan Agricultural University (03572437, 03573050, and 1921993267).

\section{References}

[1] M. C. Linder and M. Hazegh-Azam, "Copper biochemistry and molecular biology," American Journal of Clinical Nutrition, vol. 63, no. 5, pp. 797S-811S, 1996.

[2] S. Spatari, M. Bertram, K. Fuse, T. E. Graedel, and H. Rechberger, "The contemporary European copper cycle: 1 year stocks and flows," Ecological Economics, vol. 42, no. 1-2, pp. 27-42, 2002.

[3] K. Jomova and M. Valko, "Advances in metal-induced oxidative stress and human disease," Toxicology, vol. 283, no. 2-3, pp. 65-87, 2011.

[4] L. Stogdale, "Chronic copper poisoning in dairy cows," Australian Veterinary Journal, vol. 54, no. 3, pp. 139-141, 1978.

[5] M. Li, W. Cui, X. Peng, C. M. Bai, and H. M. Cui, "Effect of dietary high copper on the antioxidase activities of brain tissue in chickens," Acta Veterinaria et Zootechnica Sinica, vol. 41, pp. 220-223, 2010.

[6] M. Li, W. Cui, X. Peng, C. M. Bai, and H. M. Cui, "Effect of dietary high copper on the oxidization in brain tissue of chickens," Chinese Journal of Veterinary Science, vol. 29, pp. 1334-1337, 2009.

[7] X. Peng, K. C. Zhu, Z. Y. Xu, J. L. Deng, and H. M. Cui, “Studies on pathologic effect of high copper on organs of AA broilers," Veterinary Science in China, vol. 36, pp. 659-664, 2006.

[8] L. Zhao, F. Yang, X. Peng, J. L. Deng, and H. M. Cui, "Effects of high copper on the production of the hydroxy radical and nitrogen monoxide in liver of ducklings," Chinese Veterinary Science, vol. 38, pp. 787-790, 2008.

[9] L. Zhao, H. M. Cui, F. Yang, X. Peng, and J. L. Deng, "Effects of high dietary copper on hepatic oxidation and hepatocyte apoptosis in ducklings," Chinese Veterinary Science, vol. 38, pp. 54-58, 2008.

[10] W. Cui, X. Peng, L. Zhao, F. Yang, and H. M. Cui, "Effect of high copper on the antioxydic function of kidney in ducklings," Acta Veterinaria et Zootechnica Sinica, vol. 40, pp. 572-576, 2009.

[11] N. Ercal, H. Gurer-Orhan, and N. Aykin-Burns, "Toxic metals and oxidative stress part I: mechanisms involved in Me-tal induced oxidative damage," Current Topics in Medicinal Chemistry, vol. 1, no. 6, pp. 529-539, 2001.

[12] D. J. Buckley, P. A. Morrissey, and J. I. Gray, "Influence of dietary vitamin $\mathrm{E}$ on the oxidative stability and quality of pig meat," Journal of Animal Science, vol. 73, no. 10, pp. 31223130, 1995.

[13] K. Z. Nunes, M. Fioresi, V. B. Marques, and D. V. Vassallo, "Acute copper overload induces vascular dysfunction in aortic rings due to endothelial oxidative stress and increased nitric oxide production," Journal of Toxicology and Environmental Health, Part A, vol. 81, no. 8, pp. 218-228, 2018. 
[14] F. Yang, J. Liao, R. Pei et al., "Autophagy attenuates copperinduced mitochondrial dysfunction by regulating oxidative stress in chicken hepatocytes," Chemosphere, vol. 204, pp. 3643, 2018.

[15] K. Shimada, E. Reznik, M. E. Stokes et al., "Copper-binding small molecule induces oxidative stress and cell-cycle arrest in Glioblastoma-patient-derived cells," Cell Chemical Biology, vol. 25, no. 5, pp. 585-594.e7, 2018.

[16] A. Rakshit, K. Khatua, V. Shanbhag, P. Comba, and A. Datta, "Cu2+selective chelators relieve copper-induced oxidative stressin vivo," Chemical Science, vol. 9, no. 41, pp. 79167930, 2018.

[17] L. M. Gaetke and C. K. Chow, "Copper toxicity, oxidative stress, and antioxidant nutrients," Toxicology, vol. 189, no. 12, pp. 147-163, 2003.

[18] D. Ozcelik, R. Ozaras, Z. Gurel, H. Uzun, and S. Aydin, "Copper-mediated oxidative stress in rat liver," Biological Trace Element Research, vol. 96, no. 1-3, pp. 209-215, 2003.

[19] H. Deng, P. Kuang, H. Cui et al., "Sodium fluoride induces apoptosis in cultured splenic lymphocytes from mice," Oncotarget, vol. 7, no. 42, pp. 67880-67900, 2016.

[20] Y. B. Kabak and M. Y. Gülbahar, "Determination of apoptosis in liver and kidney tissues in experimental copper toxicity in rats," Ankara Universitesi Veteriner Fakultesi Dergisi, vol. 60, no. 1, pp. 39-45, 2012.

[21] L. I. Yu-Wen, X. H. Wan, and Q. Ning, "Excessive copper induces hepatocyte apoptosis and affects Bax and Bcl-2 expression in rat liver," Chinese Journal of Contemporary Pediatrics, vol. 10, pp. 42-46, 2008.

[22] J. Liu, H. Zhao, Y. Wang, Y. Shao, J. Li, and M. Xing, "Alterations of antioxidant indexes and inflammatory cytokine expression aggravated hepatocellular apoptosis through mitochondrial and death receptor-dependent pathways in Gallus gallus exposed to arsenic and copper," Environmental Science and Pollution Research International, vol. 25, no. 16, pp. 15462-15473, 2018.

[23] S. Borchard, F. Bork, T. Rieder et al., "The exceptional sensitivity of brain mitochondria to copper," Toxicology in Vitro, vol. 51, pp. 11-22, 2018.

[24] Y. Shao, H. Zhao, Y. Wang, J. Liu, H. Zong, and M. Xing, "Copper-mediated mitochondrial fission/fusion is associated with intrinsic apoptosis and autophagy in the testis tissues of chicken," Biological Trace Element Research, vol. 188, no. 2, article 1427, pp. 468-477, 2019.

[25] Y. Lu, Q. Luo, H. Cui et al., "Sodium fluoride causes oxidative stress and apoptosis in the mouse liver," Aging, vol. 9, no. 6, pp. 1623-1639, 2017.

[26] O. Micheau, "Regulation of TNF-related apoptosis-inducing ligand signaling by glycosylation," International Journal of Molecular Sciences, vol. 19, no. 3, p. 715, 2018.

[27] Q. Luo, H. Cui, H. Deng et al., "Histopathological findings of renal tissue induced by oxidative stress due to different concentrations of fluoride," Oncotarget, vol. 8, no. 31, pp. 50430-50446, 2017.

[28] J. Pujol, R. Fenoll, D. Macià et al., "Airborne copper exposure in school environments associated with poorer motor performance and altered basal ganglia," Brain and Behavior, vol. 6, no. 6, article e00467, 2016.

[29] S. Mitra, T. Keswani, M. Dey et al., "Copper-induced immunotoxicity involves cell cycle arrest and cell death in the spleen and thymus," Toxicology, vol. 293, no. 1-3, pp. 78-88, 2012.
[30] S. Haywood, D. M. Simpson, G. Ross, and R. J. Beynon, "The greater susceptibility of North Ronaldsay sheep compared with Cambridge sheep to copper-induced oxidative stress, mitochondrial damage and hepatic stellate cell activation," Journal of Comparative Pathology, vol. 133, no. 2-3, pp. 114-127, 2005.

[31] H. L. Tseng, C. J. Li, L. H. Huang et al., "Quercetin 3-O-methyl ether protects FL83B cells from copper induced oxidative stress through the PI3K/Akt and MAPK/Erk pathway," Toxicology and Applied Pharmacology, vol. 264, no. 1, pp. 104113, 2012.

[32] H. Guo, K. Li, W. Wang, C. Wang, and Y. Shen, "Effects of copper on hemocyte apoptosis, ROS production, and gene expression in white shrimp litopenaeus vannamei," Biological Trace Element Research, vol. 179, no. 2, pp. 318-326, 2017.

[33] J. Coccimiglio, M. Alipour, Z. H. Jiang, C. Gottardo, and Z. Suntres, "Antioxidant, Antibacterial, and Cytotoxic Activities of the Ethanolic Origanum vulgare Extract and Its Major Constituents," Oxidative Medicine and Cellular Longevity, vol. 2016, Article ID 1404505, 8 pages, 2016.

[34] B. Poljsak, D. Šuput, and I. Milisav, "Achieving the balance between ROS and antioxidants: when to use the synthetic antioxidants," Oxidative Medicine and Cellular Longevity, vol. 2013, Article ID 956792, 11 pages, 2013.

[35] W. D. Jiang, Y. Liu, K. Hu et al., "Copper exposure induces oxidative injury, disturbs the antioxidant system and changes the Nrf2/ARE (CuZnSOD) signaling in the fish brain: protective effects of myo-inositol," Aquatic Toxicology, vol. 155, pp. 301-313, 2014.

[36] W. Cui, X. Peng, J. L. Deng, and H. M. Cui, "Effects of dietary high copper on antioxidative function and observation of pathologic lesion in spleen of chick," Chinese Veterinary Science, vol. 39, pp. 338-343, 2009.

[37] M. Muthumani and S. M. Prabu, "Silibinin potentially protects arsenic-induced oxidative hepatic dysfunction in rats," Toxicology Mechanisms and Methods, vol. 22, no. 4, pp. 277-288, 2012.

[38] M. Milić, S. Žunec, V. Micek et al., “Oxidative stress, cholinesterase activity, and DNA damage in the liver, whole blood, and plasma of Wistar rats following a 28-day exposure to glyphosate," Archives of Industrial Hygiene and Toxicology, vol. 69, no. 2, pp. 154-168, 2018.

[39] M. Aghvami, F. Ebrahimi, M. H. Zarei, A. Salimi, R. Pourahmad Jaktaji, and J. Pourahmad, "Matrine induction of ROS mediated apoptosis in human ALL B-lymphocytes via mitochondrial targeting," Asian Pacific Journal of Cancer Prevention, vol. 19, no. 2, pp. 555-560, 2018.

[40] M. Arredondo and M. T. Núñez, "Iron and copper metabolism," Molecular Aspects of Medicine, vol. 26, no. 4-5, pp. 313-327, 2005.

[41] X. L. Li, Y. S. Wong, G. Xu, and J. C. N. Chan, "Seleniumenriched Spirulina protects INS-1E pancreatic beta cells from human islet amyloid polypeptide-induced apoptosis through suppression of ROS-mediated mitochondrial dysfunction and PI3/AKT pathway," European Journal of Nutrition, vol. 54, no. 4, pp. 509-522, 2015.

[42] M.-J. Hosseini, F. Shaki, M. Ghazi-Khansari, and J. Pourahmad, "Toxicity of copper on isolated liver mitochondria: impairment at complexes I, II, and IV leads to increased ROS production," Cell Biochemistry and Biophysics, vol. 70, no. 1, pp. 367-381, 2014.

[43] Q. Wei, Q. Luo, H. Liu et al., "The mitochondrial pathway is involved in sodium fluoride $(\mathrm{NaF})$-induced renal apoptosis in mice," Toxicology Research, vol. 7, no. 5, pp. 792-808, 2018. 
[44] X. Jiang and X. Wang, "Cytochrome C-mediated apoptosis," Annual Review of Biochemistry, vol. 73, pp. 87-106, 2004.

[45] F. Cecconi, G. Alvarez-Bolado, B. I. Meyer, K. A. Roth, and P. Gruss, "Apaf1 (CED-4 homolog) regulates programmed cell death in mammalian development," Cell, vol. 94, no. 6, pp. 727-737, 1998.

[46] S. Santos, A. M. Silva, M. Matos, S. M. Monteiro, and A. R. Álvaro, "Copper induced apoptosis in Caco-2 and Hep-G2 cells: expression of caspases 3, 8 and 9, AIF and p53," Comparative Biochemistry and Physiology Part C: Toxicology \& Pharmacology, vol. 185-186, pp. 138-146, 2016.

[47] E. Norberg, S. Orrenius, and B. Zhivotovsky, "Mitochondrial regulation of cell death: processing of apoptosis-inducing factor (AIF)," Biochemical and Biophysical Research Communications, vol. 396, no. 1, pp. 95-100, 2010.

[48] F. Gao, X. Lu, and G. Ren, "Regulation of mitochondria in apoptosis," Chinese Journal of Applied \& Environmental Biology, vol. 10, pp. 251-255, 2004.

[49] D. Ren, H. C. Tu, H. Kim et al., "BID, BIM, and PUMA are essential for activation of the BAX- and BAK-dependent cell death program," Science, vol. 330, no. 6009, pp. 1390-1393, 2010.

[50] L. Reshi, H.-V. Wang, C.-F. Hui, Y.-C. Su, and J.-R. Hong, "Anti-apoptotic genes Bcl-2 and Bcl-xL overexpression can block iridovirus serine/threonine kinase-induced Bax/mitochondria-mediated cell death in GF-1 cells," Fish \& Shellfish Immunology, vol. 61, pp. 120-129, 2017.

[51] M. Kawakami, R. Inagawa, T. Hosokawa, T. Saito, and M. Kurasaki, "Mechanism of apoptosis induced by copper in PC12 cells," Food and Chemical Toxicology, vol. 46, no. 6, pp. 2157-2164, 2008.

[52] H. W. Chan, T. Liu, G. Verdile et al., "Copper induces apoptosis of neuroblastoma cells via post-translational regulation of the expression of $\mathrm{Bcl}-2$-family proteins and the txJ mouse is a better model of hepatic than brain Cu toxicity," International Journal of Clinical and Experimental Medicine, vol. 1, no. 1, pp. 76-88, 2008.

[53] K. Schulze-Osthoff, D. Ferrari, M. Los, S. Wesselborg, and M. E. Peter, "Apoptosis signaling by death receptors," FEBS Journal, vol. 254, no. 3, pp. 439-459, 1998.

[54] A. Thorburn, "Death receptor-induced cell killing," Cellular Signalling, vol. 16, no. 2, pp. 139-144, 2004. 


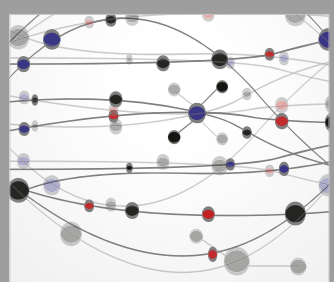

The Scientific World Journal
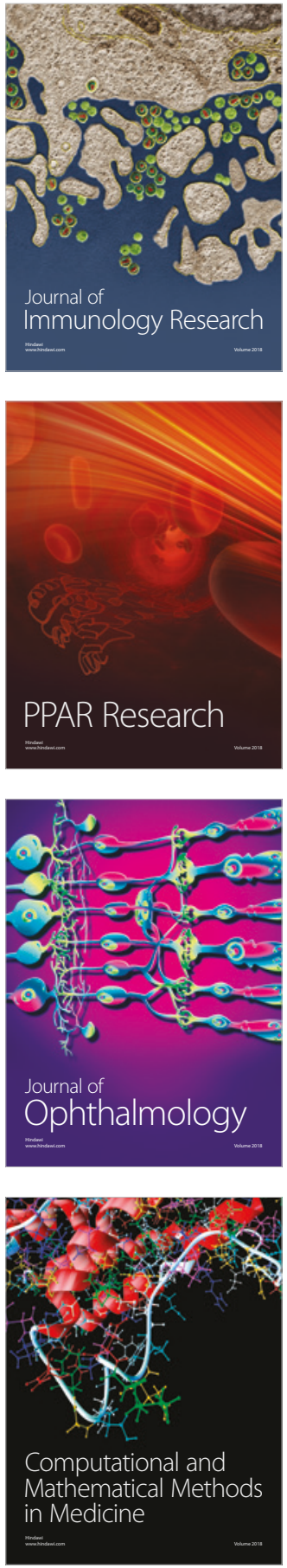

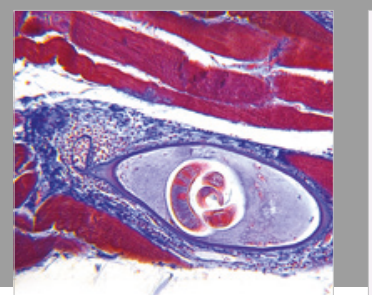

Gastroenterology Research and Practice

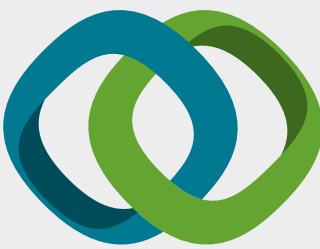

\section{Hindawi}

Submit your manuscripts at

www.hindawi.com
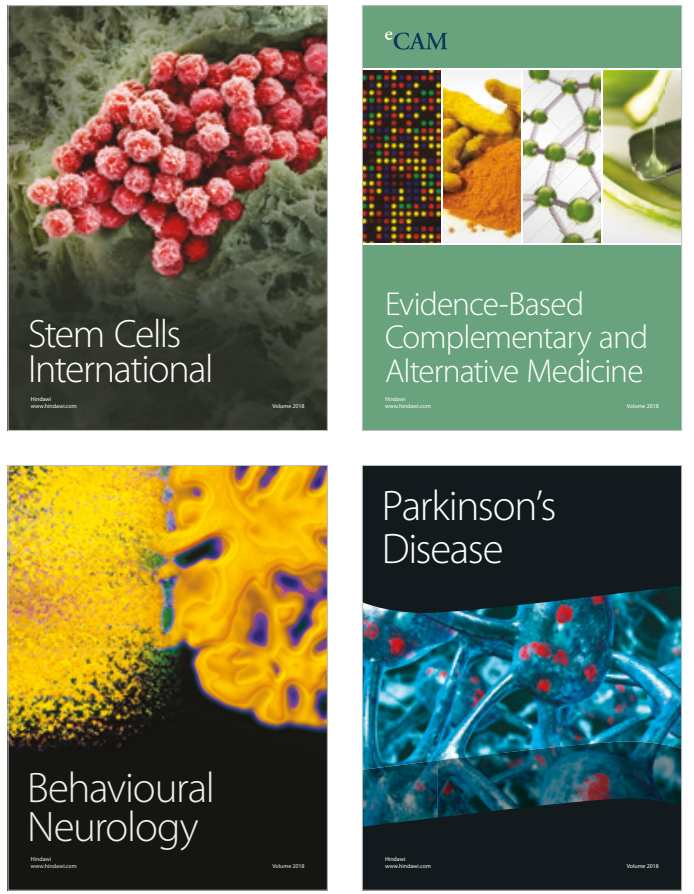

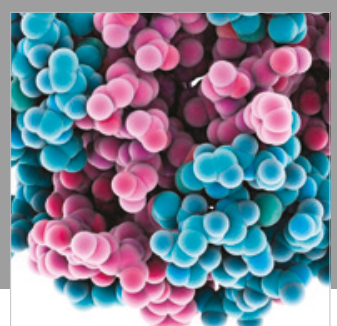

ournal of

Diabetes Research

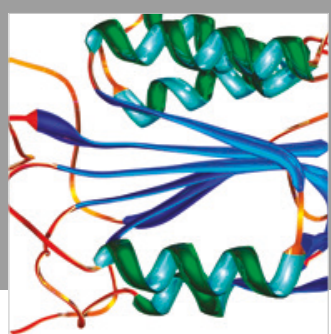

Disease Markers
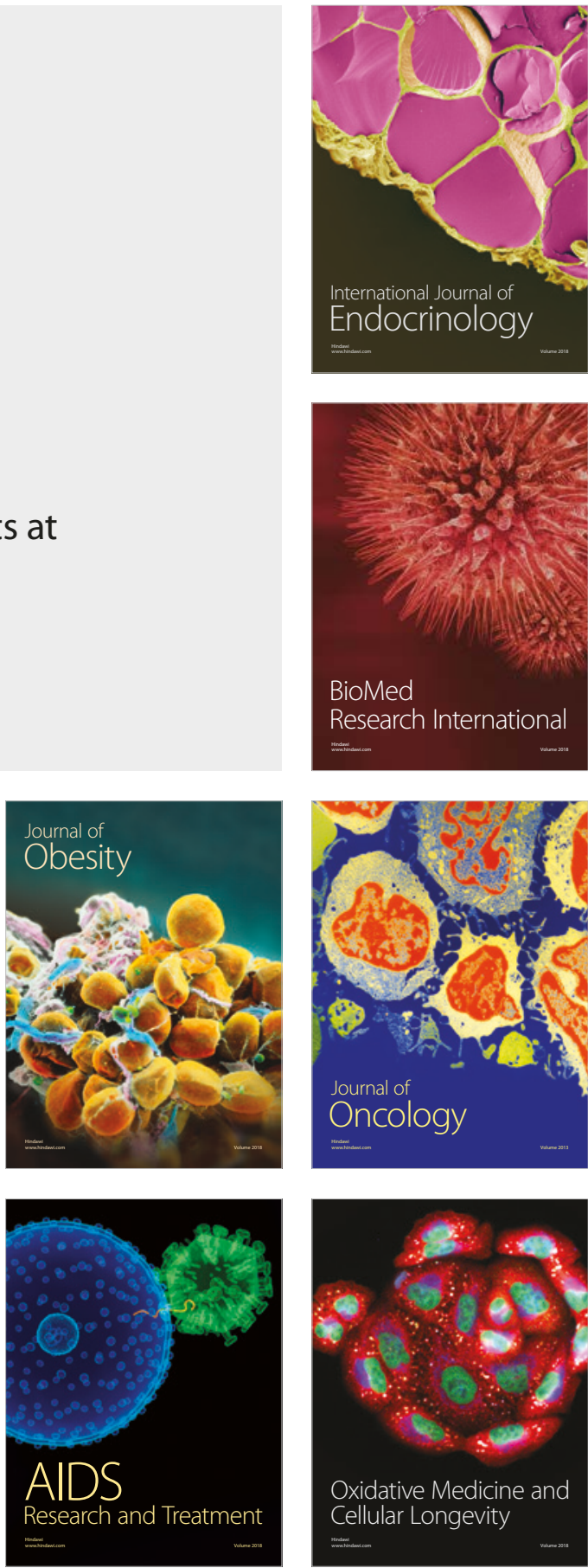